Rhode Island College

Digital Commons @ RIC

$12-2-2018$

\title{
The Use of Preemptive Ketamine for the Prevention of Postoperative Pain in Surgical Patients
}

Nicole Blake Brecher

Follow this and additional works at: https://digitalcommons.ric.edu/etd

Part of the Perioperative, Operating Room and Surgical Nursing Commons

\section{Recommended Citation}

Brecher, Nicole Blake, "The Use of Preemptive Ketamine for the Prevention of Postoperative Pain in Surgical Patients" (2018). Master's Theses, Dissertations, Graduate Research and Major Papers Overview. 290.

https://digitalcommons.ric.edu/etd/290

This Major Paper is brought to you for free and open access by the Master's Theses, Dissertations, Graduate Research and Major Papers at Digital Commons @ RIC. It has been accepted for inclusion in Master's Theses, Dissertations, Graduate Research and Major Papers Overview by an authorized administrator of Digital Commons @ RIC. For more information, please contact digitalcommons@ric.edu. 
THE USE OF PREEMPTIVE KETAMINE FOR THE PREVENTION OF POSTOPERATIVE PAIN IN SURGICAL PATIENTS: A SYSTEMATIC REVIEW

by

Nicole Blake Brecher

A Major Paper Submitted in Partial Fulfillment

of the Requirements for the Degree of

Master of Science in Nursing

in

The School of Nursing

Rhode Island College

2018 


\begin{abstract}
Post-operative pain is accompanied with strong emotional and physical responses which may often discourage the healing process. Acute pain serves as a physical warning sign to the patient but when left unchecked, the acute pain process can increase nociceptor sensitivity and ultimately lead to chronic pain syndromes. Currently, it is thought that providing pain medication to block pain receptors prior to nociception might decrease the development of, or severity of, pain. Some practitioners have used ketamine as an adjunct pain medication perioperatively to decrease pain. The purpose of this review is to investigate the efficacy of Ketamine administered in a pre-hospital or pre-surgical setting on the overall pain management of surgical patients A literature search was performed on PubMed and Medline and using the PRISMA flowchart, and appropriate studies were identified. Each study was critically appraised and organized into tables to organize related variables and results. Variables included ketamine dosing, route of administration, the use of opioid or local anesthetic for comparison, type of surgery, and the length of duration into the post-operative period that pain scores were recorded. This systematic review supports that preemptive ketamine reduces acute pain in the immediate postoperative period.
\end{abstract}




\section{Acknowledgements}

To my husband, my biggest supporter near and far. 


\section{Table of Contents}

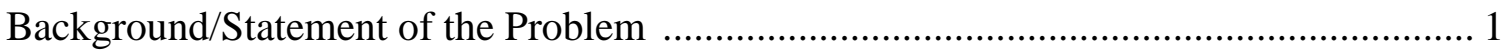

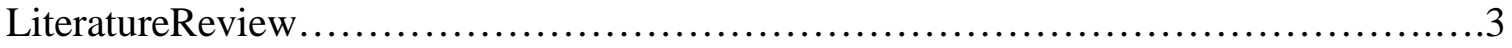

Theoretical Framework..............................................................

Method............................................................................ 15

Results.................................................................... 18

Summary and Conclusions.......................................................

Recommendations and Implications for Advanced Nursing Practice.......................40

References...................................................................42

Appendices................................................................46 
The Use of Preemptive Ketamine for Surgical and Trauma Patients: A Systematic Review

\section{Background/Statement of the Problem}

Alleviating pain and providing comfort is a cornerstone of nursing and medical practice. In recent years, the Institute of Medicine (IOM) has declared pain a public health problem costing society billions (Institute of Medicine [IOM], 2011). The IOM has placed a large emphasis on the quality of care, or the extent to which the services provided to the patient actually improve overall patient health (2011). The results of the delivered care should be optimized patient outcomes and this includes the management of pain. Not only does poor pain management lead to dissatisfied patients, but it also contributes to prolonged post-operative recovery and eventual long-term changes such a neuronal system remodeling and sensitization, chronic pain, and the stress response. This response includes increased blood clotting, impaired immune function, inflammation, lung and brain injury, breakdown of body tissue as well as a sympathetic response, or “fight or flight” (Hayes \& Gordon, 2015).

Due to an increased focus on patient-centered care and proper pain management, the use of measuring and reporting pain through various self-report or visual analogue pain scales has become common practice. The focus on patient-reported pain assessments have led to over-prescribing opioids by providers and contributes to the opioid epidemic (Hayes \& Gordon, 2015). Historically, opioid medications (morphine and fentanyl) have been used as the medication of choice for pain relief. Due to the incidence of nausea and vomiting associated with these medications, their administration is often preceded or immediately followed by an antiemetic. Additional well-documented negative side effects of opioids include accidental overdose, hypotension, respiratory depression, and 
loss of protective airway reflexes. In most prehospital trauma systems, opioids continue to be the analgesic of choice despite the narrow therapeutic range and potential for adverse outcomes (Losvik, Murad, Skjerve, \& Husum, 2015). Recently, attention has shifted to the preemptive use of Ketamine as a safe and effective drug for pain management. Ketamine provides analgesia, amnesia, protects airway responses, and has a rapid onset for quick relief (Svenson \& Abernathy, 2007).

Despite the negative outcomes associated with the use of only opioids for pain relief, as well as emerging evidence that ketamine alone or in addition to opioids for pain relief may lead to lower pain scores and more stable physiologic results for the patient, morphine (opioids) remains the staple of pain relief in healthcare. The purpose of this review is to investigate the efficacy of Ketamine administered in a pre-hospital or presurgical setting on the overall pain management of surgical patients. Data will be gathered from randomized controlled studies to examine the scientific evidence in favor for or against the use of ketamine for preemptive pain relief. The locations that data has been taken from include hospital settings prior to surgery. 


\section{Literature Review}

To examine this topic further, a literature search was performed using Pubmed and Medline. Search terms included: pain, preemptive analgesia, preemptive ketamine, trauma, and preoperative analgesia. The broad topic of the physiology of pain is first

addressed, then current analgesic practices, and finally ketamine as an analgesic and why this drug shows promise as an opioid alternative.

\section{Pain}

Pain is a somatic sensation caused by tissue damage and is accompanied by emotional and psychological factors (Kelly, Ahmad, \& Brull, 2001). Nociceptors (pain receptors) located on skin, arterial walls, joint surfaces, as well as other areas, can be activated by mechanical, chemical, or thermal stimuli and then convert these stimuli into neural impulses. Type A delta fibers are responsible for fast pain transmission and type C nerve fibers are responsible for slow, chronic pain transmission. The damaged tissues release chemical substances such as prostaglandins, bradykinins, leukotrienes, substance $\mathrm{P}$ and free-radicals that serve to promote inflammation and sensitize these pain fibers leading to a state of hyperalgesia (Kelly, Ahmad, \& Brull, 2001). Once the chemical release occurs, a pain-free state is often more difficult to attain.

With a lack of adequate pain control, peripheral sensitization occurs first in which the body initiates the inflammatory process in the primary area of injury and immediately adjacent to the injury (Farris \& Fiedler, 2001). The area of hyperalgesia amplifies nociception to thermal and mechanical stimuli. Central sensitization may occur later in which the central nervous system experiences a change in neuronal excitability in the spinal cord dorsal horn in which pain is sensed in the brain with even low-stimulation, a 
phenomenon that can persist even after the primary injury has resolved (Farris \& Fiedler, 2001).

Pain is a frequently encountered patient condition in the hospital and is often considered a normal part of the surgical and healing process. This 'par for the course' attitude leads to delayed or inadequate treatment that is often carried out via pro re nata (PRN), or 'as needed' pain medication administration scheduling traditionally with nonsteroidal anti-inflammatory drugs (NSAIDs) or opioid pain medication. Pain perception by the patient and providers is subjective and the correct course of action for treatment is unclear. When pain is left untreated, hyperalgesia, alterations in pain processing and chronic pain may ultimately develop (Kelly, et al., 2001). Chronic pain may develop from acute post-operative pain in up to $50 \%$ of patients after surgeries such as amputations, breast surgery, or inguinal hernioplasty (Wegorowski, et al., 2016).

\section{Preemptive pain medication}

The negative outcomes of untreated pain can be avoided when an analgesic is administered before a painful stimulus, such as a surgical incision, to counteract sensitization in the first place. Preventing sensitization is the basis for preemptive analgesia. It has also been well documented that preemptive use of pain medication prior to the application of noxious stimuli results in better-controlled pain versus waiting to treat pain until the noxious stimuli has already occurred (Wegorowski et al., 2016). For example, prostaglandins and leukotrienes, when released from damaged tissue increase the transduction of painful stimuli by reducing the pain threshold of peripheral pain receptors and increasing their responsiveness (Kelly, et al., 2001). By inhibiting the 
arachidonic acid pathway and blocking the formation of these chemical mediators, the pain enhancing effect of these inflammatory mediators might be prevented.

A prospective study was conducted over a 6-month period with U.S. combat forces in Afghanistan using data collected on 309 casualties from the point of injury to arrival to surgical hospitals (Shackelford et al., 2015). The purpose of this study was to evaluate the current use of prehospital pain medications used by U.S. Forces in Afghanistan and to compare vital signs before and after pain medication administration. The authors found that prehospital pain medication administration to trauma patients with morphine, fentanyl or ketamine all resulted in decreased pain scores on a numerical scale upon arrival to the hospital and resulted in better overall pain management (Shackelford et al., 2015). The authors also found that when Ketamine was used for pain relief it resulted in a higher blood pressure (Shackelford et al., 2015). This effect of Ketamine proves to be advantageous in shock patients and supports the Defense Health Board's recommendation that ketamine be used for analgesia in this specific patient population (Shackelford et al., 2015). Currently, ketamine is the first-line pain medication for casualties in shock or at risk for shock (Shackelford et al., 2015). Besides pain control, the preemptive use of pain medication has also been linked to a decrease in posttraumatic stress disorder development among civilian and combat casualties (Shackelford et al., 2015).

A double-blind study performed by Wegorowski et al. (2016) aimed to evaluate the effects of analgesics used pre-emptively on the level of post-operative pain intensity felt by female patients after surgical treatment of breast cancer. The study included 100 patients with an average age of 59 years who had breast operations for breast cancer that 
included simple and radical mastectomies, quadrantectomies, local excision and sentinel node biopsy. The patients were divided into four groups, three of which received preemptive analgesia (Metamizole, Tramadol, or Ketoprofen) prior to induction for anesthesia. One group received no pain medication. Data was collected at $6,12,18$, and 24 hours post-operatively. The authors found that patients had significantly less pain post-operatively when they received preemptive pain medication (in this case, tramadol or ketoprofen) than those patients who did not receive any medication, thus highlighting the effectiveness of preemptive pain medication on post-operative pain control (Wegorowski et al, 2016).

Researchers Grube, Milad, and Damme-Sorenen (2004) conducted a randomized, double-blind study to explore the effect of preemptive analgesia in patients undergoing laparoscopic procedures and the degree of postoperative pain. The study, conducted from 2000 to 2001, included 164 patients: 85 randomized to the study group receiving analgesia and 79 in the control group received no preemptive analgesia. The authors found that the overall mean pain scores and incisional pain scores did not differ at 4 hours post-operatively or 24 hours post operatively for both study and control groups. The results are contradictory to most available literature. The study found that preemptive analgesia did not reduce post-operative pain in this population (Grube, Milad, and Damme-Sorenen, 2004).

\section{Ketamine}

Ketamine is considered a dissociative anesthetic and works by blocking the Nmethyl-d-aspartate acid receptor and preventing the hyper-excitability of the spinal cord neurons and central sensitization to peripheral nociceptor stimulation (Oliveira, Sakarta, 
\& Martins, 2005). Preventing central sensitization is the main objective of preemptive analgesia. Studies have found that concentrations of ketamine in the brain were directly related to analgesic levels: using functional magnetic resonance imagining (fMRI), pain activation areas in the brain (somatosensory cortex, thalamus, anterior cingulate cortex) showed decreased activity when ketamine was given which correlates with a decrease in pain sensing and pain processing (Niesters, et al., 2012).

Ketamine had also been found to possess activity at the $\mu$ receptor in rats and the $\kappa$ receptor in guinea pigs suggesting a similar effect in human models (Smith, et al., 1987). This theory has been supported by studies that have found that analgesia, when obtained via the use of ketamine, can be decreased when naloxone is given (Stella, Crescenti, \& Torri, 1984). This phenomenon suggests the ability of ketamine to be used not only as an analgesic but also as an opioid-sparing drug. The ability of ketamine to decrease the amount of administered opioid to achieve pain relief has implications for the United States which is suffering from the over-used and over-prescribed opioid epidemic.

Opioids have typically been the analgesic of choice for prehospital trauma pain relief. Opioids are not without harmful side effects that may be amplified in situations where a first responder is unable to provide uninterrupted monitoring. Decreased levels of consciousness can result from opioid use, whether in large doses or not, causing airway blockage and decreased oxygenation and this has been reported as a common cause of avoidable death in trauma patients (Tran, et al., 2014).

Ketamine is a sympathomimetic and generally causes varying degrees of increased heart rate and blood pressure stability, it is considered preferable for use in trauma or shock patients and has been recommended by the Committee on Tactical 
Combat Casualty Care as a first line analgesic (Shackelford, et al., 2015). Ketamine contrasts with opioids such as morphine in that patients with sub-anesthetic doses (but high enough for analgesia) can maintain their airway. Ketamine causes minimal respiratory suppression (Shackelford, et al., 2015). Some reported side effects of ketamine include nausea/vomiting, dysphoria, agitation, and disorientation.

\section{Preemptive Ketamine}

A retrospective study by Svenson and Abernathy (2007) was conducted to review the experience of the use of ketamine in a regional air ambulance setting. The authors found that pain relief for burn patients was only achieved with the addition of ketamine after already being treated with large doses of narcotics. The study took place from January 2003 to June 2006 and included 40 patients who were given Ketamine during the aeromedical evacuation program. Ages ranged from two months to seventy-five years old and included trauma, burn, cardiac and respiratory patients. The researchers found that all cardiac patients were hypotensive and required intubation to protect the airway but that after ketamine was administered blood pressure was maintained. Two patients were assessed to have difficult airways, so ketamine was administered for airway safety in place of narcotics. All patients that received ketamine for pain/sedation maintained airway responsiveness and oxygen saturations. The authors concluded that "ketamine is a safe and effective drug to use in the prehospital environment” and that there are a "variety of situations in which ketamine may be more appropriate than the current more common field medications” (Svenson \& Abernathy, 2007, p. 978).

A retrospective comparative study was conducted over a ten-year span in warzones in North and Central Iraq to investigate the effects of prehospital analgesia on 
physiologic trauma severity indicators, specifically with the use of ketamine and pentazocine. This study included adult trauma patients 15 years and older and variables measured included blood pressure, respiratory rate, level of consciousness and injury severity as a reflection of pain. ISS scores of 75 are considered incompatible with life and these patients, along with patients scoring an ISS of one, were excluded from this study. The final sample study included 1,876 patients. Comparisons were done using ANOVA and associations were found using GLM linear regression model. Researchers found that in patients with an Injury Severity Score greater than 8 (moderate to severely injured) who received ketamine had significantly better physiologic outcomes and treatment effects than opioid use alone, including respiratory rate and blood pressure (Losvik, Murad, Skjerve, and Husum, 2015). The authors also found that receiving analgesia, whether narcotic or ketamine, was associated with a better blood pressure score but those patients with more serious injuries that received ketamine had a significant positive change in systolic blood pressure. Both narcotic and ketamine were associated with a negative impact on the level of consciousness. This study also showed that prehospital analgesia, narcotic or ketamine, was associated with an overall improvement of physiological severity indicators (Losvik, Murad, Skjerve, \& Husum, 2015).

Authors Johansson, Kongstad and Johansson (2009) conducted a prospective clinical cohort study in Sweden with 27 bone fracture patients who received either morphine or morphine with ketamine. Data was collected at the scene of rescue and then later at admission to the hospital and the data included level of pain, nausea/vomiting, systolic blood pressure, heart rate and oxygen saturations. The authors discovered that values for pain during admission to the hospital were significantly lower in the morphine- 
ketamine combination treatment group and that those patients delivered to the hospital after treatment for morphine alone were in moderate to severe pain according to the pain scores. The authors also concluded that adding low-dose ketamine to a standard morphine dose improves hemodynamics but that additional doses of ketamine will increase the incidence of nausea and vomiting.

A prospective, cluster-randomized study conducted in rural Vietnam with 308 patients aimed to compare the analgesic effects and side effects with the use of morphine and ketamine in prehospital trauma care. The average age was 36 years, most patients studied were male and suffered from road traffic accidents. Using the Visual Analogue Scale (VAS) for pain scoring, the authors found that ketamine yielded a comparable analgesic effect to that provided by morphine but that ketamine provided greater airway protection and less nausea/vomiting (Tran, et al., 2014).

In summary, preemptive pain medication promotes positive health outcomes for patients. The use of ketamine as a preemptive analgesic is promising in that many individual studies demonstrate equivalent or superior analgesia with the added benefit of stable vitals and better airway control. Further study analysis follows. 


\section{Theoretical Framework}

Good's middle-range theory of balance will be used to guide research and translate findings to real-life health care practices. The theory focuses on the balance between attaining a pain-free state versus the side-effects and poor outcomes of the medication used to achieve this state of analgesia (Fitzpatrick \& Wallace, 2006). The theory includes the use of a multimodal approach to minimize the side effects of one drug but still to achieve analgesia, as well as frequent assessments for pain, side-effects and negative outcomes of the drug itself so that individual responses to medications can be managed (Fitzpatrick \& Wallace, 2006). Good's theory also includes patient participation and goal-setting to determine what is an acceptable level of pain per the patient so that complications from pain medication can be reduced

In addition to Good's middle-range theory, Preferred Reporting Items for Systematic Reviews and Meta-Analyses (PRISMA) was used as an evidence-based checklist and guideline for researchers in reporting and consolidating randomizedcontrolled studies in the form of a systematic review. This is presented below in Table 1. This analytic framework helps to highlight common themes, outcomes of interest, and relationships between variables. The PRISMA checklist includes specific guidelines for what should be reported in each section of the systematic review, including rationale, objectives, eligibility criteria for studies, documentation of the search, synthesis of results, risk of bias in each individual study included, summary of all evidence, application, and conclusion (Moher et al., 2009).

The purpose of PRISMA is to aid the reader in understanding the protocol and processes involved in selecting and appraising research articles. This is particularly 
important for systematic reviews as these pieces of evidence are used in establishing new practices in the health care field (also known as evidenced-based practice) due to their rigor. Systematic reviews are based on pre-established guidelines and protocols that are designed for transparency, replicability and integrity. It is then easier for the reader to determine bias (Moher et al., 2009).

Table 1

PRISMA Checklist 


\begin{tabular}{|c|c|c|c|}
\hline Section/Topic & $\begin{array}{l}\text { Item } \\
\#\end{array}$ & Checklist Item & $\begin{array}{l}\text { Reported on } \\
\text { Page \# }\end{array}$ \\
\hline \multicolumn{4}{|l|}{ TITLE } \\
\hline Title & 1 & Identify the report as a systematic review, meta-analysis, or both. & \\
\hline \multicolumn{4}{|c|}{ 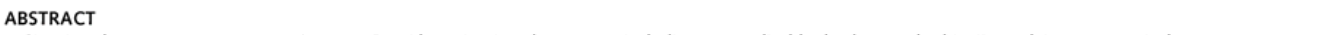 } \\
\hline Structured summary & 2 & $\begin{array}{l}\text { Provide a structured summary including, as applicable: background; objectives; data sources; study } \\
\text { eligibility criteria, participants, and interventions; study appraisal and synthesis methods; results; } \\
\text { limitations; conclusions and implications of key findings; systematic review registration number. }\end{array}$ & \\
\hline \multicolumn{4}{|l|}{ INTRODUCTION } \\
\hline Rationale & 3 & Describe the rationale for the review in the context of what is already known. & \\
\hline Objectives & 4 & $\begin{array}{l}\text { Provide an explicit statement of questions being addressed with reference to participants, } \\
\text { interventions, comparisons, outcomes, and study design (PICOS). }\end{array}$ & \\
\hline \multicolumn{4}{|l|}{ METHODS } \\
\hline Protocol and registration & 5 & $\begin{array}{l}\text { Indicate if a review protocol exists, if and where it can be accessed (e.g., Web address), and, if } \\
\text { available, provide registration information including registration number. }\end{array}$ & \\
\hline Eligibility criteria & 6 & $\begin{array}{l}\text { Specify study characteristics (e.g., PICOS, length of follow-up) and report characteristics (e.g., } \\
\text { years considered, language, publication status) used as criteria for eligibility, giving rationale. }\end{array}$ & \\
\hline Information sources & 7 & $\begin{array}{l}\text { Describe all information sources (e.g., databases with dates of coverage, contact with study } \\
\text { authors to identify additional studies) in the search and date last searched. }\end{array}$ & \\
\hline Search & 8 & $\begin{array}{l}\text { Present full electronic search strategy for at least one database, including any limits used, such } \\
\text { that it could be repeated. }\end{array}$ & \\
\hline Study selection & 9 & $\begin{array}{l}\text { State the process for selecting studies (i.e., screening, eligibility, included in systematic review, } \\
\text { and, if applicable, included in the meta-analysis). }\end{array}$ & \\
\hline Data collection process & 10 & $\begin{array}{l}\text { Describe method of data extraction from reports (e.g., piloted forms, independently, in duplicate) } \\
\text { and any processes for obtaining and confirming data from investigators. }\end{array}$ & \\
\hline Data items & 11 & $\begin{array}{l}\text { List and define all variables for which data were sought (e.g., PICOS, funding sources) and any } \\
\text { assumptions and simplifications made. }\end{array}$ & \\
\hline $\begin{array}{l}\text { Risk of bias in individual } \\
\text { studies }\end{array}$ & 12 & $\begin{array}{l}\text { Describe methods used for assessing risk of bias of individual studies (including specification of } \\
\text { whether this was done at the study or outcome level), and how this information is to be used } \\
\text { in any data synthesis. }\end{array}$ & \\
\hline Summary measures & 13 & State the principal summary measures (e.g., risk ratio, difference in means). & \\
\hline Synthesis of results & 14 & $\begin{array}{l}\text { Describe the methods of handling data and combining results of studies, if done, including } \\
\text { measures of consistency }\left(\text { e.g., } 1^{2}\right) \text { for each meta-analysis. }\end{array}$ & \\
\hline $\begin{array}{l}\text { Risk of bias across } \\
\text { studies }\end{array}$ & 15 & $\begin{array}{l}\text { Specify any assessment of risk of bias that may affect the cumulative evidence (e.g., publication } \\
\text { bias, selective reporting within studies). }\end{array}$ & \\
\hline Additional analyses & 16 & $\begin{array}{l}\text { Describe methods of additional analyses (e.g., sensitivity or subgroup analyses, meta-regression), if } \\
\text { done, indicating which were pre-specified. }\end{array}$ & \\
\hline \multicolumn{4}{|c|}{ 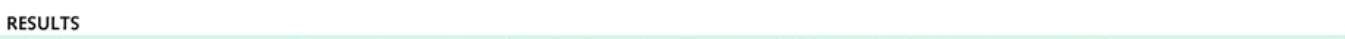 } \\
\hline Study selection & 17 & $\begin{array}{l}\text { Give numbers of studies screened, assessed for eligibility, and included in the review, with reasons } \\
\text { for exclusions at each stage, ideally with a flow diagram. }\end{array}$ & \\
\hline Study characteristics & 18 & $\begin{array}{l}\text { For each study, present characteristics for which data were extracted (e.g., study size, PICOS, } \\
\text { follow-up period) and provide the citations. }\end{array}$ & \\
\hline $\begin{array}{l}\text { Risk of bias within } \\
\text { studies }\end{array}$ & 19 & $\begin{array}{l}\text { Present data on risk of bias of each study and, if available, any outcome-level assessment (see } \\
\text { Item 12). }\end{array}$ & \\
\hline $\begin{array}{l}\text { Results of individual } \\
\text { studies }\end{array}$ & 20 & $\begin{array}{l}\text { For all outcomes considered (benefits or harms), present, for each study: (a) simple summary data } \\
\text { for each intervention group and (b) effect estimates and confidence intervals, ideally with a } \\
\text { forest plot. }\end{array}$ & \\
\hline Synthesis of results & 21 & $\begin{array}{l}\text { Present results of each meta-analysis done, including confidence intervals and measures of } \\
\text { consistency. }\end{array}$ & \\
\hline $\begin{array}{l}\text { Risk of bias across } \\
\text { studies }\end{array}$ & 22 & Present results of any assessment of risk of bias across studies (see Item 15). & \\
\hline Additional analysis & 23 & $\begin{array}{l}\text { Give results of additional analyses, if done (e.g., sensitivity or subgroup analyses, meta-regression } \\
\text { [see Item } 16] \text { ). }\end{array}$ & \\
\hline \multicolumn{4}{|l|}{ DISCUSSION } \\
\hline Summary of evidence & 24 & $\begin{array}{l}\text { Summarize the main findings including the strength of evidence for each main outcome; consider } \\
\text { their relevance to key groups (e.g., health care providers, users, and policy makers). }\end{array}$ & \\
\hline Limitations & 25 & $\begin{array}{l}\text { Discuss limitations at study and outcome level (e.g., risk of bias), and at review level (e.g., } \\
\text { incomplete retrieval of identified research, reporting bias). }\end{array}$ & \\
\hline Conclusions & 26 & $\begin{array}{l}\text { Provide a general interpretation of the results in the context of other evidence, and implications } \\
\text { for future research. }\end{array}$ & \\
\hline \multicolumn{4}{|l|}{ FUNDING } \\
\hline Funding & 27 & $\begin{array}{l}\text { Describe sources of funding for the systematic review and other support (e.g., supply of data); } \\
\text { role of funders for the systematic review. }\end{array}$ & \\
\hline
\end{tabular}

The PRISMA four-phase diagram (Figure 1) lays out the literature search process itself. This diagram displays how the researcher selected the articles appraised for the 
systematic review. In this way, the search may be replicated so that the inclusion of all relevant studies may be confirmed.

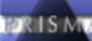

PRISMA 2009 Flow Diagram
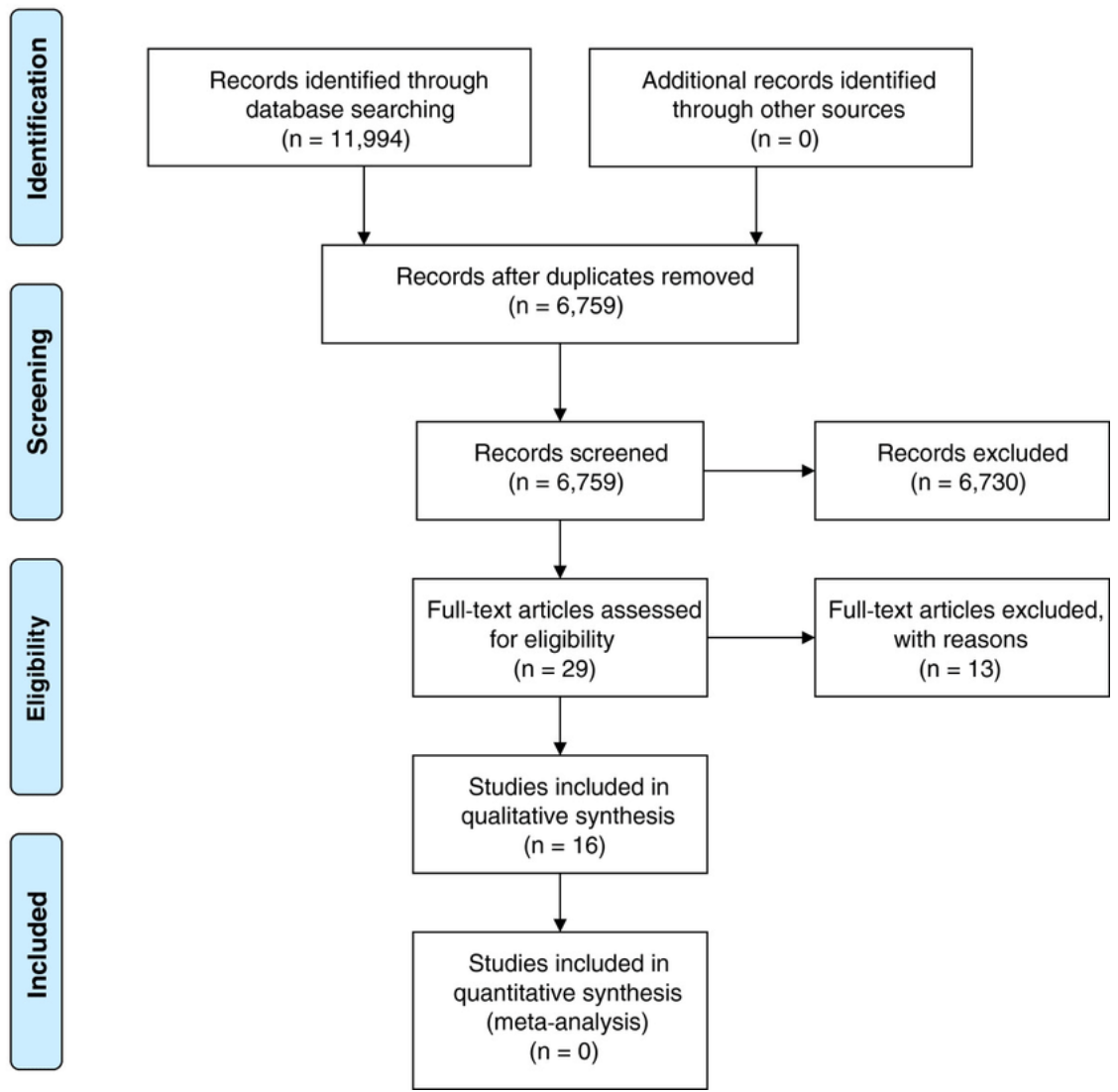

From: Moher D, Liberati A, Tetzlaff J, Altman DG, The PRISMA Group (2009). Preferred Reporting Items for Systematic Reviews and Meta-

Figure 1. PRISMA Flow Diagram 


\section{Purpose}

\section{Method}

The purpose of this review is to investigate the efficacy of Ketamine administered in a pre-hospital or pre-surgical setting on the post-operative pain management of trauma and surgical patients.

\section{Inclusion/Exclusion Criteria}

In selecting randomized controlled studies to include in this review, some limitations were set. Included in this study are randomized controlled trials of preemptive Ketamine usage in minimally invasive or major surgeries, elective or emergent surgeries, peer-reviewed studies and patients with American Society of Anesthesiologists (ASA) scores I-V. An assignment of ASA 1 score indicates a healthy patient. With each increasing score, the patient is considered to have an increasing number of uncontrolled comorbidities that ultimately may affect the outcome of the anesthesia itself. A classification of ASA V indicates a severely sick patient who will not survive without the operation but is not necessarily expected to tolerate anesthesia. An ASA V assignment indicates that poor outcomes from the procedure are expected.

Exclusion criteria included studies performed greater than 10 years ago (before 2008), and studies written in foreign languages. Studies conducted with the pediatric population (children below the age of 18 years) were also excluded due to the lack of randomized controlled trials (RCTs) conducted in this population as well as the difficulty of determining the level of pain a child is experiencing due to low quality and inaccurate pediatric pain-assessment scales, particularly with self-report pain scales.

\section{Search Strategy}


A literature search was performed using Pubmed and Medline databases via the PRISMA guideline. An initial search for “ketamine” and "pain management” yielded a total of 1,366 articles. Additional searches were performed by adding keywords such as “prehospital”, “preoperative”, and placing limitations such as studies written in English and published in peer review journals. The articles were then narrowed down to 41 total. After excluding pediatric populations, studies completed prior to 2008, and including only randomized controlled studies, seven final articles were included in this review. Keywords used in this search were as follows: Ketamine, preoperative, prehospital, pain management, trauma, analgesia.

\section{Data Collection}

A critical appraisal tool known as Critical Appraisal Skills Programme (CASP), was used to critically appraise each RCT included in this systematic review. This is presented below in Table 2. Through a 10-item checklist, the clarity of results, the validity and reliability of results and data collection, as well as the usefulness and reallife application of the data was determined for each article. The data gathered from each study was collected, organized and separated into charts to delineate common themes or outcomes. The data tables help to determine whether the studies support or refute each other. 
Table 2.

\section{Critical Appraisal Skills Programme (CASP)}

\begin{tabular}{|l|l|}
\hline A) Are the results of the trial valid? & Yes Can't Tell No \\
\hline 1. Did the trial address a clearly focused issue? & \\
\hline 2. Was the assignment of patients to treatments randomized? & \\
\hline $\begin{array}{l}\text { 3. Were all the patients who entered the trial properly accounted } \\
\text { for at its conclusion? }\end{array}$ & \\
\hline $\begin{array}{l}\text { 4. Were patients, health workers and study personnel "blind" to } \\
\text { treatment? }\end{array}$ & \\
\hline 5. Were the groups similar at the start of the trial? & \\
\hline 6. Aside from the experimental intervention, were the groups \\
treated equally?
\end{tabular}

(Singh, 2013) 


\section{Results}

Based on the inclusion criteria, a total of seven studies were included in this systematic review. Summaries of the studies, including a general description of design, sample, method, and results, are presented in the following paragraphs.

To assess the effect of pre-emptive ketamine on post-amputation pain, authors Wilson, Nimmo, Fleetwood-Walker and Colvin (2008) conducted a randomized doubleblind study with 53 patients undergoing lower limb amputation (Appendix A.1). Patients assigned to group K received epidural bupivacaine $0.125 \%$ and racemic ketamine 3.3 $\mathrm{mg} / \mathrm{kg} / \mathrm{l}$ via continuous infusion. Patient assigned to group S received epidural bupivacaine $0.125 \%$ and $\mathrm{NaCl} 0.9 \%$ via continuous infusion. Following surgery, the epidural infusion was maintained within a range of $10-20 \mathrm{ml} / \mathrm{h}$ as needed for adequate analgesia (defined as VAS $\leq 30$ ). If the maintenance infusion was inadequate, boluses of 10-15 ml were given. Analgesia was supplemented with paracetamol 1 gram every 6 hours orally as needed. All epidurals ran for 48-72 hours and no other analgesic was provided. If all medications failed to provide adequate analgesia, the patient was removed from the study. The period of epidural analgesia, motor block, number of epidural boluses, average VAS scores and negative side effects were recorded. The authors used the incidence of stump pain and phantom pain as primary outcome measures.

Statistical analysis was performed using Chi-squared analysis or Fisher’s exact test as appropriate. ANOVA was also used to compare nonparametric data. Using these methods to assess data, the authors found that both groups had improved postoperative analgesia when compared to the patients' preoperative pain state (see Appendix B.1). Group K had significantly lower pain scores than group S and required less epidural 
boluses during the in-hospital postoperative phase. Mean epidural infusion rate and duration were kept constant between the groups. There was no significant difference between motor blockade for the duration of the epidural infusion between the two groups. The overall analgesic drugs prescribed did not vary between groups. Phantom and stump pain assessed at 8 days, 6 weeks, 3 months, 6 months and 12 months did not vary significantly between the two groups. There was also no detectable frequency in attacks between the groups during this time-period. Side effects such as nausea, vomiting, confusion and sedation were low and incidences were similar between groups (Wilson, et al., 2008).

This study by Wilson et al. met all criteria outlined in the CASP worksheet (Appendix C.1). The study was transparent with a clearly focused issue, randomized treatment groups and patient assignments, and all patients were properly accounted for from beginning to end of trial. This study was easy to follow. Results can be applied to the clinical setting and all clinically important outcomes were considered.

Researchers Behdad, Hosseinpour, and Khorasani (2011) evaluated 80 adult male patients undergoing an operation for acute appendicitis to determine whether the preemptive use of ketamine decrease post-operative pain (Appendix A.2). Patients were randomly divided into two groups. In the operating room, the ketamine group received $0.5 \mathrm{mg} / \mathrm{kg}$ of ketamine IV 10 minutes prior to surgical incision. The control group received $0.5 \mathrm{mg} / \mathrm{kg}$ normal saline IV. All patients were pre-medicated with midazolam $0.05 \mathrm{mg} / \mathrm{kg}$ IV. Patients were then induced with thiopental $6 \mathrm{mg} / \mathrm{kg}$ and atracurium 0.5 $\mathrm{mg} / \mathrm{kg}$. For maintenance, isoflurane $0.5-1 \%, 50 \%$ nitrous oxide, and $50 \%$ oxygen were used. Using the VAS, pain intensity was assessed at time 0 (immediately after arousal), 
4, 12, and 24 hours post-operatively. The time interval for first request of analgesia was recorded as well as total number of times additional analgesia was requested in PACU during the first 24 hours. This information stated above is presented in Appendix A, table A.2.

Behdad, Hosseinpour, and Khorasani (2011) found that for all evaluated postoperative times, the VAS scores were significantly lower in the ketamine group compared to the control group. The interval time to first analgesic request was also longer in the ketamine group than the control group. $42.5 \%$ of the patient in the ketamine group did not require any addition analgesic post-operatively. Data are presented in Appendix B.2.There were no drug side effects in the ketamine group. Data were presented as mean standard deviation for quantitative variables. The Mann Whitney test was used to compared VAS scores across groups, as well as the time for first analgesic and total amount of analgesic. Statistical analysis was done with SPSS 11.5 (SPSS Inc., Chicago, USA). A P-value less than 0.05 was considered significant.

To critique this article, the CASP checklist for randomized control trials was used (Appendix C.2). The authors clearly defined the issue of post-operative pain for acute appendicitis. The assignment of patients to treatment groups was randomized and the surgeon and research physician responsible for data collection were unaware of the patient assignment. All patients were accounted for in the study (there were no dropouts). Basic variables of the patients were illustrated in a table showing consistency in both groups with age, duration of surgery and duration of anesthesia. Aside from the experimental intervention, it was unclear whether both groups were treated equally. Anesthetically, induction medications were consistent between groups as well as 
maintenance medications. However, surgically the authors only stated that a Mcburney incision for the appendectomy was performed. It is unclear whether further surgical variation occurred from patient to patient. The results are applicable clinically to this treatment group, and important outcomes were considered including side effects. Midazolam was appropriately given to all patients to avoid any side effects of the ketamine treatment, so harm to the patients was dutifully avoided (Behdad, Hosseinpour, \& Khorasani, 2011).

Researchers Ryu, Lee, Kim, and Bahk (2011) examined the effect of preemptive low-dose thoracic epidural analgesia on the incidence of chronic post-thoracotomy pain by conducting a prospective, double-blinded, randomized controlled trial (Appendix A.3). 133 patients were enrolled ranging from 19 years of age to 81 and using an Excel program-generated randomization table, the patients were randomized into two groups. Group KF (Ketamine-free) received thoracic patient-controlled epidural analgesia with $0.12 \%$ levobupivacaine and $2 \mathrm{mg} / \mathrm{mL}$ of fentanyl making up a total volume of $500 \mathrm{ml}$. Group K (Ketamine) received the same epidural infusion with additional $100 \mathrm{mg}$ preservative-free ketamine at $0.2 \mathrm{mg} / \mathrm{ml}$ concentration. For both groups the epidural infusion was programmed to administer a loading dose of $6 \mathrm{ml}$, a background infusion of $6 \mathrm{ml} / \mathrm{hr}$, and a bolus dose of $0.5 \mathrm{ml}$ (on demand) with a lockout interval of 20 minutes. Both groups received the loading dose immediately upon arrival to the operating room where the adequacy of the block was verified. Then, both groups underwent general anesthesia using similar medications and dosing for induction and intubated with either double-lumen tubes or uninvent tubes. Maintenance of anesthesia was done using 1 to 1.5 
MAC of sevoflurane or desflurane. One surgeon performed all the procedures to provide consistency with surgical technique and approach (Appendix A.3).

Pain at two weeks and three months post-operatively was measured at rest and during coughing using the VAS score. The presence of allodynia and numbness at the thoracotomy scar was also recorded. Using the Stata IC 10, a sample size of at least 65 for each group was needed to prove statistical significance with data results. Statistical analysis was performed using Stata IC 10, 2-sample t test, and Fisher exact test to compare data between the two groups. A P value of less than 0.05 was considered significant. In the data collection table (Appendix B.3), all P values are higher than 0.05. Therefore, the authors concluded that low-dose ketamine, when added to thoracic epidural analgesia, did not make any significant difference in the incidence of postthoracotomy pain. Preemptive ketamine also did not have a measurable effect on the incidence of allodynia or numbness at 3 months after surgery. This data is presented in Appendix B.3.

The CASP checklist was used to select this article for review (Appendix C.3). In this clinical trial, the authors clearly addressed the clinical problem, illustrated the selection and exclusion of patients, indicated that all health workers and study personnel were blind to the treatment, and outlined the general anesthesia and surgical process to emphasize consistency throughout the trial. Both experimental groups were similar at the start of the trial. Side effects of the epidural and any additional analgesic drugs used were not discussed. The results of this study can only rule out the use of low-dose ketamine as beneficial. Higher doses of ketamine might have produced significant results that would be relevant and applicable clinically. 
Singh et al. (2013) performed a double-blinded randomized trial to evaluate the efficacy of preemptive analgesia using intravenous ketamine 30 minutes prior to surgical incision in patients undergoing laparoscopic cholecystectomy (Appendix A.4. This study used 80 adult patients of both female and male gender and ASA values of I or II. Patients were placed into one of four groups with 20 patients each. Group A received ketamine $1.0 \mathrm{mg} / \mathrm{kg}$, Group B patients received ketamine $0.75 \mathrm{mg} / \mathrm{kg}$, Group C patients received $0.50 \mathrm{mg} / \mathrm{kg}$ and Group D received isotonic saline only. All doses were diluted in fixed volumes of $10 \mathrm{~mL}$ for each patient. All patients received the same pre-operative medications. The same drugs, procedure for induction, and maintenance of anesthesia was also held constant for each patient across groups. Patients were then extubated prior to transfer to the PACU (Appendix A.4).

In the PACU, patients were observed for pain intensity and relief using the visual analogue scale (VAS) and the verbal rating scale (VRS). These scores were obtained every half hour for two hours, every one hour for the following four hours, at 12 hours post-operatively and 24 hours post-operatively. Each time scores were recorded, the patient was evaluated at rest, at slight movement, and at deep breathing. Supplemental analgesia was administered using IV boluses of $1 \mathrm{mcg} / \mathrm{kg}$ Fentanyl when patient requested to allow comparison of opioid consumption between groups 24 hours postoperatively. Adverse effects associated with medication were also recorded such as nausea, vomiting and hallucinations. The sample size of 20 patients per group gave a power of $80 \%$ at an $\alpha$ - level of 0.05 . Using the SPSS statistical program (SPSS Inc., Chicago, IL, USA), t-test and analysis of variance test, data of the different groups were compared. The Chi-square test was also complete for analysis of qualitative data. Fisher's 
exact test was used to analyze the incidence of side effects and number of patients receiving rescue analgesic (Singh et al., 2013). This is located in Appendix B.4.

The authors found the average VAS scores were significantly higher in Group D immediately after surgery ( 0 and 0.5 hours post-operatively) as well as hours 3, 4, 5, 6, and 12 when compared to all other groups at rest (Appendix B.4). VAS scores between groups $\mathrm{A}, \mathrm{B}$, and $\mathrm{C}$ at $0,0.5,1.0,1.5$, and 2 hours post-operatively were comparable with no significant variation. VAS scores at hours 1, 1.5 and 2 post-operatively were comparable in all four groups. VAS scores on deep breathing were higher than VAS scores recorded at rest and slight movement across all groups. Overall, the authors concluded that the VAS scores and total opioid consumption were higher when compared to Groups A, B and C at most of the time intervals. The mean time to rescue analgesia was significantly longer in Groups A, B, and C. The incidence of nausea and vomiting were comparable across all groups. Hallucinations occurred in $10 \%$ of subjects in Group A and $0 \%$ in all other groups (Singh et al., 2013).

A critical evaluation of the Singh et al. (2013) study using the CASP worksheet found that the authors met all criteria presented. This is presented in Appendix C.4. The authors clearly identified the issue with thorough background information. Patients were randomly assigned to groups and accounted for throughout study. The authors stated that the demographic profile was statistically comparable between groups and all study personnel were blind to treatment groups. Materials and methods were detailed enough as to determine that all groups were treated equally. The results are relevant to surgical settings and all clinically important outcomes were considered, including side effects of medications (Appendix C.4). 
Authors Jennings et al., (2014) conducted a long-term prevalence study of a randomized controlled trial examining the use of ketamine versus morphine for prehospital traumatic pain (Appendix A.5). A total of 97 patients were followed from December 2007 to July 2010. Patients were randomly assigned to one of two groups and received either a ketamine bolus of $20 \mathrm{mg}$ intravenously followed by $10 \mathrm{mg}$ every 3 minutes, or if allocated to the morphine group the patient received 5 mg intravenous morphine every 5 minutes. Both groups were treated until pain free. After discharge from the hospital, the patients were contacted by telephone within 6-12 months. During the interview, the researchers used the Physical Component Summary (PCS), the Mental Component Summary (MCS), and the Verbal Numerical Rating Scale (VNRS). The PCS and MCS scales assess the perceptions of pain, energy, mental health, social functioning, and any physical limitations of the patient. The PCS and MCS scores between the two groups were compared using the two-sample t test for continuous variables. Numeric pain scale data were compared using the two-sample Wilcoxon rank-sum test. Treatment effects were considered significant at 0.05 .

The researchers concluded that there was no significant difference in the longterm follow-up between study groups despite citing evidence from previously conducted studies demonstrating that early analgesic interventions reduce the incidence of chronic pain after surgery. Of significance in this study was that a total of $45 \%$ of participants from both groups reported persistent pain because of their surgical injury. This information is presented in Appendix B, Table B.5.

Using the CASP worksheet to critically evaluate this study found that the authors met all but one criteria (Appendix C.5). Patient assignments were randomized, all 
patients were accounted for from beginning to end, patients and personnel were blind to treatment and the groups were all treated equally. The authors did address that not all clinically important outcomes were considered, and that "time to treatment" data was not available to the researchers. The authors stated that this covariate may have been an important consideration when looking at clinically important outcomes. The results of this study can be applied to a clinical context, having this addition information would have made stronger results.

In a prospective, double-blind randomized controlled study, Khashan et al. (2016) examined the effect of preemptive intra-articular morphine and ketamine on pain after arthroscopic rotator cuff repair (Appendix A.6). 45 patients, male and female, above 18 years of age participated. All participants had partial or complete rotator cuff tears. Three groups of 15 each were created with each group receiving an allotted treatment 20 minutes prior to surgery via intra-articular injection (20 mg or morphine, $50 \mathrm{mg}$ ketamine and $10 \mathrm{mg}$ of morphine, or $10 \mathrm{~mL}$ of $0.9 \%$ saline). All medications were injected in the subacromial space with the same technique using an 18-gauge needle. Standardized general anesthesia was then performed for each patient in beach chair position. Initial vital signs were recorded in PACU as well as pain scores via the Numeric Rating Scale (NRS). In PACU, all patients were hooked up to intravenous patient-controlled analgesia pumps (PCA) that delivered $1.5 \mathrm{mg}$ morphine for each bolus with a seven minute lockout time. Oral paracetamol 1,000 mg and oxycodone $5 \mathrm{mg}$ were also available to all patients upon request every six hours.

Pain scores were evaluated every 30 minutes in PACU and every eight hours on the orthopedic floor by blinded nurses. Secondary outcomes of this study included the 
amount of PCA morphine used by each patient as well as the amount of requested rescue medication use. Post-discharge pain levels and drug consumption were reported using a daily pain diary over the next three months. One-way analysis of variance (ANOVA) was used to compare numeric scale parameters between the three groups. The authors found that PACU and three-month post-discharge NRS scores were comparable between the groups. The combined ketamine and morphine group’s pain scores were not statistically different from the other groups. Second week post-op pain scores declined significantly in the morphine-only and saline-only group. The NRS scores were significantly lower in the morphine-only group than the saline-only group during the time spent on the orthopedic floor and the first two weeks postoperatively. The authors concluded that preoperative intra-articular injection of ketamine and morphine did not produce preferable responses to pain relief versus morphine alone. Rescue analgesic consumption between all three groups also supported this conclusion. This data is presented in Appendix B, Table B.6.

Critical evaluation of the Khashan et al. (2016) study using the CASP worksheet found that ten of eleven specific criteria were met. The authors clearly defined an issue within healthcare and detailed the blinding process throughout the study, as seen in Appendix C.6. The authors accounted for all the enrolled patients in the clinical trial via an illustrated flowchart. The groups were held to the same inclusion and exclusion criteria as clearly stated within the study. Although stated by the authors that “standardized general anesthesia” was administered, it is unknown how adjuvant analgesia administered intra-operatively varied from patient to patient. The results of this study are relevant to surgical environments with orthopedics. 
Researchers Lin and Jia (2016) conducted a randomized, prospective, doubleblinded study with 90 patients scheduled for elective laparoscopic surgery to evaluate the effects of intravenous ketamine on visceral pain (Appendix A.7). Preoperatively, patients were trained for use of the visual analogue scale (VAS) and then randomly assigned to one of three groups. Group 1 received an intravenous placebo, normal saline. Group 2 received preincision normal saline intravenously as well as local infiltration with $80 \mathrm{mg}$ ropivacaine at the end of surgery. Group 3 received preincision ketamine $0.3 \mathrm{mg} / \mathrm{kg}$ and local infiltration with $80 \mathrm{mg}$ ropivacaine. All groups received injections of equivalent volume. The anesthetic and surgical techniques were all standardized between patients of all three groups. Patients were then brought to PACU where assessment of parietal pain and visceral pain was initiated using the VAS.

Parietal pain is defined as superficial pain on the abdominal wall and visceral pain is defined as deep, dull pain deep inside the abdomen. VAS scores were obtained at 2, 6, 12, and 24 hours postoperatively. Shoulder pain was also recorded. A standardized method to treat post-operative pain using tramadol and meperidine based off severity of the VAS score was used. Quantitative data was compared between groups by analysis of variance and post-hoc testing. Statistical significance was assumed if $\mathrm{P}>0.05$. Qualitative data between groups was analyzed using the chi-square tests. The Statistical Package for Social Sciences (SPSS, Inc., USA) was used for statistical analysis (Lin \& Jia, 2016).

The authors Lin and Jia (2016) found that the VAS scores for visceral pain in group 3 were significantly lower than the pain scores in groups 1 and 2 at 2 and 6 hours post-operatively. This data is presented in Appendix B.7. Groups 1 and 2 showed no statistically significant difference in pain scores at hours 2 and 6. At hours 2 and 6, the 
VAS scores were similar between groups 2 and 3 and both groups had significantly lower scores than group 1. All groups were comparable with visceral and incisional pain scores at 12 and 24 hours post-op. The time to first analgesic request was also documented in PACU. These scores were comparable in groups 2 and 3 which were both significantly longer than the times recorded for group 1. Group 1 also received higher doses overall of meperidine than the other groups. Differences in total analgesic consumption between groups 2 and 3 did not reach statistical significance. It was also noted that the incidence of post-operative nausea and vomiting was similar in all three groups (Lin \& Jia, 2016).

The CASP checklist for randomized control trials was also used to critique this study (Appendix C.7). The trial clearly defines the issue of postoperative visceral pain after laparoscopic gynecological surgery. The authors clearly state that patients were randomized to treatment groups and outlined patient characteristics (age, ASA category, weight, duration of surgery) across groups to illustrate no statistically significant difference. Authors Lin and Jia (2016) also accounted for all patients who entered the trial: of the 90 patients enrolled, two were excluded due to the need to place an intraabdominal drain in one and the need for conversion to an open procedure for another patient. Groups 1-3 had 29, 29, and 30 patients complete the study, respectively. Standard anesthetic and surgical techniques were outlined and similar across all groups. Clinically important outcomes were considered, including side effects. The results are applicable to clinical care of similar patients.

\section{Cross-Study Analysis}

All studies included for analysis were randomized controlled trials. The study conducted by Jennings et al. was the only long-term follow up randomized controlled 
trial to investigate the effects of preemptive ketamine on pain six to twelve months after treatment. Descriptive data synthesis of the included studies is illustrated in Appendix D. All studies included a large enough sample size to determine statistical significance $(\mathrm{p}<$ 0.05). The variables across studies included the dosing of ketamine itself, the route of administration of ketamine, and the length of time into the post-operative period that pain scores were recorded.

Four of the collected studies investigated the use of intravenously administered ketamine. When examining ketamine dosing, the Singh et al. (2013) study is the only included study that addressed the variability of ketamine dosing itself. Using doses of ketamine in descending order, Groups A, B and C (respectively) all reported significantly decreased pain scores and decreased opioid consumption in the post-operative period. Group D who received isotonic saline reported the highest pain scores. There was no difference between average pain score of the three groups indicating that increased ketamine dosing is not always more effective at relieving pain and that there might be a ceiling effect in terms of pain control. In fact, Singh et al. (2013) found that Group A with the highest dose of ketamine at $1.0 \mathrm{mg} / \mathrm{kg}$ reported the most side effects, such as high blood pressure, tachycardia, and hallucinations. This is significant for all other studies included in this systematic review because all other studies compared only one dose of ketamine with a control group using isotonic saline or another drug in a separate analgesic class. This suggests that using different doses of ketamine may not have necessarily altered pain scores in the other studies. The Singh et al. (2013) study reported administration of the highest intravenous dose of ketamine at $1.0 \mathrm{mg} / \mathrm{kg}$, suggesting that 
doses lower than this are appropriate for pain relief as well as decreasing adverse side effects.

The second variable examined across studies was the route of administration. Intravenous, epidural and intra-articular administration is compared in the following paragraphs. The Behdad, Hosseinpour and Khorasani (2011) study used only ketamine and isotonic saline, intravenous, as their primary pain interventions. Like the Singh et al (2013) study, there was no comparison of the efficacy of ketamine to a local anesthetic or opioid. Both studies yielded similar results in that the groups treated with ketamine had significantly lower pain scores than their isotonic solution counterparts and they both discovered that total opioid consumption in the post-operative period was less in the ketamine-treated groups.

Researchers Lin and Jia (2016) also investigated the effects of preemptive intravenous ketamine on post-operative pain in women undergoing elective gynecological laparoscopic surgery. The researchers found that group three who received local infiltration with ropivacaine and IV ketamine had significantly lower pain scores post-operatively than group two (local infiltration with ropivacaine alone) or the control group one (IV normal saline only) (Lin \& Jia, 2016). The authors also reported that consumption of additional analgesics was significantly higher in group one. Like authors Behdad, Hosseinpour, and Khorasani (2011) and Singh et al. (2013), Lin and Jia (2016) concluded that IV ketamine is effective in producing post-operative pain relief when compared to no intervention or local infiltration alone up to six hours post-operatively. Jennings et al. (2014) researched long-term post-operative pain with intravenous ketamine versus intravenous morphine given on hospital arrival to patients who sustained 
musculoskeletal trauma. Jennings et al. (2014) found that the prevalence of pain, as measured by the Physical Component Scale (PCS), the Mental Component Summary (MCS) and the Verbal Numeric Rating Scale (VNRS) were approximately the same in the ketamine-treated group versus the morphine group. $46 \%$ of respondents stated there was persistent pain in the morphine group and $44 \%$ of respondents in the ketamine group (Jennings et al., 2014). Researchers in this study concluded that there was no significant difference in long term post-operative pain scores in patients treated with IV ketamine versus IV morphine.

Two of the studies used in this systematic review were conducted looking at preemptively modulating central sensory input via ketamine administration by the spinal or epidural route. Wilson et al. (2008) used this approach when studying the effects of preemptive ketamine on lower limb amputations. Wilson et al. (2008) found that ketamine, when administered with bupivacaine infusion in a combined spinal-epidural anesthetic, yielded similar pain relieving results as a combined spinal-epidural with bupivacaine alone: the pain-relieving effects between groups did not differ. In addition, the overall number of analgesic drugs administered post-operatively in both groups was similar, and at 12 months post-operatively the number of analgesic drugs prescribed was the same for both groups.

Researchers Ryu, Lee, Kim and Bahk (2011) investigated epidurally administered ketamine on post-thoracotomy pain and found that it did not improve pain with movement or rest at two weeks or three months post-operatively any more than an epidural administered without ketamine. There was also no difference in chronic postthoracotomy pain, allodynia, or numbness at three months after surgery between both 
groups. Both studies concluded that ketamine, when given with spinal or epidural administration, did not provide any additional reduction in pain when compared with traditional local anesthetic/opioid combination.

Kashan et al. (2016) conducted a study looking at preemptive intra-articular (IA) ketamine-morphine cocktail (KM) versus morphine (M) alone and saline (S) alone on post-operative pain management in patients undergoing arthroscopic rotator cuff repair. Researchers found that in the first 14 post-operative days, group M's pain scores did not differ significantly from group KM’s values, but both groups had significantly lower pain scores than control group S. The three month pain scores did not differ significantly between group M or group KM. Kashan et al. (2016) concluded that preoperative intraarticular administration of ketamine was not superior over the use of morphine alone. Kashan et al. also stated that neither IA morphine nor IA ketamine were effective in longer-term post-operative pain management.

A third common variable between the studies included the time in the postoperative period that data collection began. Behdad et al. (2011) found that IV ketamine at a dose of $0.5 \mathrm{mg} / \mathrm{kg}$ was effective at relieving pain up to 24 hours post-op when compared to no other analgesic. Singh et al. (2017) found that pain scores were highest in the group that did not receive ketamine for 24 hours post-operatively. Authors Lin and Jia (2016) found that IV ketamine was also effective at relieving post-op pain, but only for visceral pain up to six hours post-operatively. The researchers found that the pain scores began to equalize at the 12 and 24-hour post-operative mark when gathering data (Lin \& Jia, 2016). This suggests that intravenous ketamine, when administered preemptively for post-operative pain relief, may only have a limited window of effectiveness in the post- 
operative period, possibly only up until 24 hours. Examining the Jennings et al. (2014) study, the authors investigated long-term pain prevalence and found no statistically significant difference between the ketamine group and morphine group when data collection started six months post-operatively. This study illustrates that IV ketamine is not effective in managing chronic post-operative pain which is consistent with the findings of the other studies looking at IV ketamine and the lack of efficacy in the treatment of long-term or chronic pain. This differs from the aforementioned studies using intravenous ketamine who obtained data in the acute post-operative period and found that ketamine had positive effects on pain relief. If Jennings et al. began data collection sooner, results may have been different. Wilson et al. (2008) stated epidural ketamine was ineffective for managing post-operative pain but the researchers only began data collection on post-operative day eight. It is possible, like the previously mentioned intravenous studies demonstrated, that ketamine may have had an effect on the acute pain felt in the immediate post-operative period. To determine this, data collection would need to begin in the post-operative care unit (PACU). Ryu et al. (2011) were unable to determine whether ketamine had a significant impact on post-operative pain relief. Researchers for this study began data collection two weeks into the post-operative period again indicating that they may have missed the therapeutic response to acute pain. This study and the Wilson et al. (2008) study suggest that, like intravenous ketamine, epidural ketamine is ineffective for chronic pain management. Epidural ketamine's effects on acute pain is still undetermined and would require further research.

Khashan et al. (2016) was the only study examining intra-articular administration of ketamine. Pain scores were obtained in the acute post-operative period in PACU as 
well as into the chronic pain period. The researchers did not find any benefit to the addition of ketamine for pain relief, regardless of time frame of data collection. 


\section{Summary and Conclusions}

Surgical trauma incites nociceptive pain sensitization and this acute pain, when left untreated or undertreated, can develop into chronic pain long term (Wegorowoski et al., 2016). The mechanism by which this occurs isn’t fully understood, but peripheral signaling of tissue damage and pain ultimately can lead to altered central pain processing and development of chronic pain or hyperalgesia states (Kelly, Ahmad, \& Brull, 2001). The idea of pre-emptive pain management involves thwarting the development of central sensitization in the first place. By using multi-modal pain medication, multiple pain pathways might be modified or blocked allowing for a more complete and thorough painfree state (Wegorowoski et al., 2016). This includes local anesthetics, opioids, nonsteroidal anti-inflammatories, mediating the GABA response, and NMDA-receptor antagonists. Multi-modal therapy approaches cover a wider-range of pain transmission and lessen the side effects of any one drug (Kelly, Ahmad, \& Brull, 2011). Recent interest in the NMDA receptor as a target for substance $\mathrm{P}$ in pain transmission in the dorsal horn has turned some focus onto the use of Ketamine (an NMDA-receptor antagonist) as an adjunct or alternative pain medication. By blocking "wind-up” in the dorsal horn, this may decrease pain transmission and central sensitization and lessen the chance of chronic pain development (Kelly, Ahmad, \& Brull, 2011).

The purpose of this review is to investigate the efficacy of Ketamine administered in a pre-surgical setting on the post-operative pain management of surgical patients. Outcomes were assessed with pain scores and total amount of additional analgesic requested. A comprehensive literature search was performed and the Preferred Reporting 
Items for Systematic Reviews and Meta-Analyses (PRISMA) flowchart was used to identify applicable studies that might be included or excluded (Moher et al., 2009). Each of the included studies was critically appraised using the Critical Appraisal Skills Programme (CASP) illustrated in Table 2. The basics of each study, the variables and outcomes as well as the individual CASP is illustrated in charts located in Appendices A, B and C. Lastly, a cross-study analysis was done to examine and compare key variables and outcomes. This is located in Appendix D.

Overall, low-dose intravenous ketamine used preemptively can decrease pain scores and additional analgesic/opioid consumption in the immediate post-operative period. This is supported by Lin \& Jia (2016), Singh et al. (2017), and Behdad et al. (2011). The researchers found that this was effective at least up until six hours postoperatively and in some cases up to 24 hours post-op. Jennings et al. (2014) was the only study using intravenous ketamine that found that it was not superior in terms of pain relief to the control group. The study compared IV ketamine to another IV analgesic (morphine). The researchers also looked at the effects of ketamine on long-term pain and began to data collect at six months post-op. Jennings et al. (2014) were able to conclude that ketamine provided similar analgesia in the long-term post-op period as morphine, but neither were very effective.

Morphine and ketamine work by different mechanisms (mu receptor and NMDA receptor respectively) and can be used in conjunction. These drugs also have different side effect profiles and therefore may be more or less appropriate for certain patient populations. A limitation of the Jennings et al. (2014) study was the loss of data due to lack of follow-up from participants. Long-term follow-up was only completed for $72 \%$ of 
the participants which may affect the study's validity. Looking at the characteristics profile of the patients who responded and the patients who did not respond to surveyors, there is little difference (Jennings et al., 2014). Another consideration is that data collection began at six months post-op: if data were collected in the immediate postoperative period (24 hours or less), would ketamine have been found to be a more effective analgesic?

There is a distinction between acute and chronic pain. The Jennings et al. (2014) study examined preemptive pain relief in determining the effect on chronic pain. Chronic pain is defined as pain outlasting the normal time of healing and becomes a disease state itself (Grichnik \& Ferrante, 1991). The other three studies examining preemptive intravenous ketamine collected pain scores in the acute setting. Acute pain is the result of a specific injury (surgery) and serves a biological purpose (Grichnik \& Ferrante, 1991). To determine if preemptive intravenous ketamine is effective in preventing chronic pain, more studies would be needed.

There were several limitations associated with this systematic review. The route of administration of ketamine varied as well as the dosages. Some dosages were flat numbers and remained consistent between patients while other dosages were weightbased and therefore variable between patients. The types of surgeries also varied, so the level of pain stimulation was not consistent across studies: different healing times and post-operative pain levels would be expected. These variations made comparisons difficult. Additionally, some researchers reported side effects (whether negative or positive) in the discussion of their research while others did not consider it an integral part in reporting the results. 
In summary, this systematic review supports the cautioned use of intravenous ketamine in adult surgical patients to manage short-term acute pain. More studies are needed to determine the effectiveness of epidural ketamine on acute post-operative pain. Further, the use of intra-articular ketamine may be effective, but not superior to morphine. The use of ketamine in the management of long-term pain requires more research but did not prove effective in this systematic review for any route of administration. 


\section{Recommendations and Implications for Advanced Nursing Practice}

The purpose of a systematic review is to discuss and critically analyze controlled trials testing similar subject matter as that found in a clinical setting. By comparing findings from the studies, information can be synthesized to guide clinical practice and decision making. Pre-emptive ketamine is currently controversially used in clinical practice for pain prevention and treatment. This practice is not well defined including different routes of administration, different doses and different times of administration in the perioperative period. Further research on the use of ketamine in the clinical setting, administration and effectiveness via different routes, and the effect on pain will help educate medical practitioners and guide them to better decision-making for improved patient outcomes.

Although ketamine cannot definitively be recommended to prevent acute pain post-operatively, it does show positive results in reducing pain when administered intravenously, epidurally, or intra-articularly with an adjunct or used alone. Intravenous ketamine did show a more consistent and precise improvement in pain scores than ketamine administered via epidural or intra-articular routes. However, these alternative routes of administration should not be ruled out as they also yielded pain relief: further research on proper dosing and timing of epidural and intra-articular ketamine administration is needed.

These findings relate back to Good's middle range theory on pain management which calls for a multimodal pain approach to allow for maximal coverage of pain receptors and decreased negative side effects associated with excessive use of any one 
medication. Of the studies that reported side effects, no study reported an increase of negative side effects with the addition of ketamine to an opioid or local anesthetic. The Singh et al. (2013) study supports the use of multimodal pain management for more effective pain relief and decreased side effect profile. Group A who received the highest dose of ketamine had no further pain relief but a $10 \%$ incidence of hallucinations whereas all other groups reported no hallucinations (Singh et al., 2013). In fact, Wilson et al. (2008) reported a noticeable decrease in depression levels up to one year after treatment in patients with lower limb amputations when compared to the control group without ketamine. The application of this research to the clinical setting may allow for improved post-op pain control, decreased opioid consumption, and decreased side effects of opioid consumption (such as nausea, vomiting, constipation, hypersensitivity, dependence, and sedation). While ketamine did not prove to be effective in preventing chronic pain, multimodal approaches should continue to be researched for application in the clinical setting. 


\section{References}

Behdad, A., Hosseinpour, M., \& Khorasani, P. (2011). Preemptive use of ketamine on post-operative pain of appendectomy. The Korean Journal of Pain, 24(3), 137140.

Farris, D. \& Fiedler, M. (2001). Preemptive analgesia to postoperative pain management. American Association of Nurse Anesthetists Journal, 69(3), 223-228.

Fitzpatrick, J. \& Wallace, M. (2006). Encyclopedia of nursing research (2 ${ }^{\text {nd }}$ ed.). New York, NY: Springer Publishing Company, Inc.

Grichnik, K., \& Ferrante, F. (1991). The difference between acute and chronic pain. Mt Sinai Journal of Medicine, 58(3), 217-220.

Grube, J., Milad, M., \& Damme-Sorenen, J. (2004). Preemptive analgesia does not reduce pain or improve postoperative functioning. Journal of the Society of Laparoendoscopic Surgeons, 8, 15-18.

Hayes, K. \& Gordon, D. (2015). Delivering quality pain management: the challenge for nurses. AORN Journal, 101 (3), 327-337.

Institute of Medicine. (2011). Relieving pain in America: A blueprint for transforming prevention, care, education, and research. Retrieved from https://iprcc.nih.gov/sites/default/files/IOM_Pain_Report_508C.pdf

Jennings, P., Cameron, P., Bernard, S., Walker, T., Jolley, D., Fitzgerald, M., \& Masci, K. (2014). Long-term pain prevalence and health-related quality of life outcomes for patients enrolled in a ketamine versus morphine for prehospital traumatic pain 
randomized controlled trial. Emergency Medicine Journal, 31, 840-843. doi:

10.1136/emermed-2013-202862

Johansson, P., Kongstad, P., \& Johansson, A. (2009). The effect of combined treatment with morphine sulphate and low-dose ketamine in a prehospital setting. Scandinavian Journal of Trauma, Resuscitation and Emergency Medicine, 17 (61), 1-5. doi: 10.1186/1757-7241-17-61

Kelly, D., Ahmad, M., \& Brull, S. (2001). Preemptive analgesia I: physiological pathways and pharmacological modalities. Canadian Journal of Anesthesia, 48(10), 1000-1010.

Khashan, M., Dolkart, O., Amar, E., Chechik, O., Sharfman, Z., Mozes, G., Maman, E., \& Weinbroum, A. (2016). Effect of preemptive intra-articular morphine and ketamine on pain after arthroscopic rotator cuff repair: a prospective, doubleblind, randomized controlled study. Arthroscopy and Sports Medicine, 136, 233239. doi: 10.1007/s00402-015-2346-Z

Lin, H., \& Jia, D. (2016). Effect of preemptive ketamine administration on postoperative visceral pain after gynecological laparoscopic surgery. Journal of Huazhong University of Science and Technology, 36(4), 584-587. doi: 10.1007/s11596-0161629-0

Losvik, O., Murad, M., Skjerve, E., \& Husum, H. (2015). Ketamine for prehospital trauma analgesia in a low-resource rural trauma system: a retrospective comparative study of ketamine and opioid analgesia in a ten-year cohort in Iraq. 
Scandinavian Journal of Trauma, Resuscitation and Emergency Medicine, 23 (94), 1-8. doi: 10.1186/s13049-015-0176-1

Moher, D., Liberati, A., Tatzlaff, J., Altman, D. (2009). Preferred reporting items for systematic reviews and meta-analysis: The PRISMA statement. PLoS Med, 6(7). 1-6. doi: 10.1371/journal.pmed1000097

Niesters, M., Khalili-Mahani, N., Martini, C., Aarts, L., van Gerven, J., van Buchem, M., Dahan, A., Rombouts, S. (2012). Anesthesiology, 117(4), 868-877.

Oliveira, C., Issy, A., Sakata, R., Carcia, J., Martins, G. (2005). Preemptive effect of IV S(+)-ketamine for hysterectomy. Acute Pain, 7, 139-143.

Ryu, H., Lee, C., Kim, Y., \& Bahk, J. (2011). Preemptive low-dose epidural ketamine for preventing chronic postthoracotomy pain: A prospective double-blinded, randomized, clinical trial. Clinical Journal of Pain, 27(4), 304-208.

Shackelford, S., Fowler, M., Schultz, K., Summers, A., Galvagno, S., Gross, K., Mabry, R., Bailey, J., Kotwal, R., \& Butler, F. (2015). Prehospital pain medication use by U.S. forces in Afghanistan. Military Medicine, 180, 304-309.

Singh, H., Kundra, S., Singh, R., Grewal, A., Kaul, T., \& Sood, D. (2013). Preemptive analgesia with ketamine for a laparoscopic cholecystectomy. Journal of Anesthesiology Clinical Pharmacology, 29 (4), 478-484.

Singh, J. (2013). Critical appraisal skills programme. Journal of pharmacology and Pharmacotherapeutics, 4(1), 76. 
Smith, D., Bouchal, R., deSanctis, C., Monroe, R., Amedro, J., Perrotti, J., \& Crisp, T. (1987). Properties of the interaction between ketamine and opiate binding site in vivo and in vitro. Neuropharmacology, 26(9), 1253-1260.

Stella, L., Crescenti, A., \& Torri, G. (1984). Effect of naloxone on the loss of consciousness induced by I.V. anaesthetic agents in man. British Journal of Anaesthesia, 56(4), 369-373.

Svenson, J. \& Abernathy, M. (2007). Ketamine for prehospital use: New look at an old drug. The American Journal of Emergency Medicine, 25, 977-980.

Wegorowski, P., Stanistawek, A., Domzat-Drzewicka, R., Sysiak, J., Rzaca, M., Milanowska, J., Janiszewska, M, Dziubinska, A. (2016). The effect of preemptive analgesia on the level of postoperative pain in women undergoing surgery for breast neoplasm. Contemporary Oncology, 20(2), 158-164.

Wilson, J., Nimmo, A., Fleetwood-Walker, S., \& Colvin, L. (2008). A randomized double blind trial of the effect of the pre-emptive epidural ketamine on persistent pain after lower limb amputation. Pain, 135, 108-118. 
Appendix A

Study Descriptions

Table A.1

Wilson, J., Nimmo, A., Fleetwood-Walker, S., \& Colvin, L. (2008). A randomized double blind trial of the effect of the pre-emptive epidural ketamine on persistent pain after lower limb amputation. Pain, 135, 108-118.

\begin{tabular}{|c|c|c|c|c|c|}
\hline Aim & $\underline{\text { Design }}$ & Site & $\underline{\text { Sample }}$ & Method & Outcome \\
\hline $\begin{array}{l}\text { To assess the effect of } \\
\text { preemptive treatment with } \\
\text { an epidurally administered } \\
\text { NMDA receptor antagonist, } \\
\text { ketamine, in combination } \\
\text { with local anesthetic, on } \\
\text { reducing spinal sensory } \\
\text { transmission, acute central } \\
\text { sensitization and the } \\
\text { development of persistent } \\
\text { post-amputation pain. }\end{array}$ & $\begin{array}{l}\text { Double blind, } \\
\text { randomized control } \\
\text { trial. } \\
\text { Group K- } 0.125 \% \\
\text { bupivacaine with } \\
3.3 \mathrm{mg} / \mathrm{kg} / \mathrm{L} \\
\text { ketamine via } \\
\text { epidural infusion } \\
\text { Group S- } 0.125 \% \\
\text { bupivacaine with } \\
0.9 \% \text { saline via } \\
\text { epidural infusion } \\
\text { Mean epidural } \\
\text { infusion rates and } \\
\text { duration was the } \\
\text { same for both } \\
\text { groups. }\end{array}$ & $\begin{array}{l}\text { Royal } \\
\text { Infirmary of } \\
\text { Edinburgh, } \\
\text { Scotland }\end{array}$ & $\begin{array}{l}47 \text { total patients } \\
\text { included in the } \\
\text { study, } 21 \text { patients } \\
\text { in Group K, } 26 \\
\text { patients in Group } \\
\text { S. } \\
\text { VAS* scores were } \\
\text { similar between } \\
\text { groups pre- } \\
\text { operatively. } \\
\text { Patients excluded } \\
\text { from the study } \\
\text { included patients } \\
\text { with previous } \\
\text { lower limb } \\
\text { amputations or } \\
\text { those unable to fill } \\
\text { out the } \\
\text { questionnaire. }\end{array}$ & $\begin{array}{l}\text { Rate of phantom and } \\
\text { stump pain were } \\
\text { assessed at } 8 \text { days, } 6 \\
\text { weeks, and } 3 \text { months } \\
\text { post-op using VAS } \\
\text { scores. } \\
\text { Block height, motor } \\
\text { block, number of } \\
\text { epidural bolus doses, } \\
\text { respiratory rate, and } \\
\text { presence of N/V were } \\
\text { also recorded during } \\
\text { epidural infusion } \\
\text { period. } \\
\text { SigmaState for } \\
\text { Windows, chi-squared } \\
\text { analysis, Fisher's } \\
\text { exact test, and } \\
\text { ANOVA were used } \\
\text { for data analysis. }\end{array}$ & $\begin{array}{l}\text { There was no } \\
\text { addition } \\
\text { reduction in } \\
\text { persistent pain in } \\
\text { the ketamine } \\
\text { group versus the } \\
\text { local anesthetic } \\
\text { group at one } \\
\text { year. } \\
\text { There was a } \\
\text { reduction of pain } \\
\text { in the acute post- } \\
\text { operative period } \\
\text { in the ketamine } \\
\text { group. }\end{array}$ \\
\hline
\end{tabular}


Table A.2

Behdad, A., Hosseinpour, M., Khorasani, P. (2011). Preemptive use of ketamine on post-operative pain of appendectomy. The Korean Journal of Pain, 24(3), 137-140.

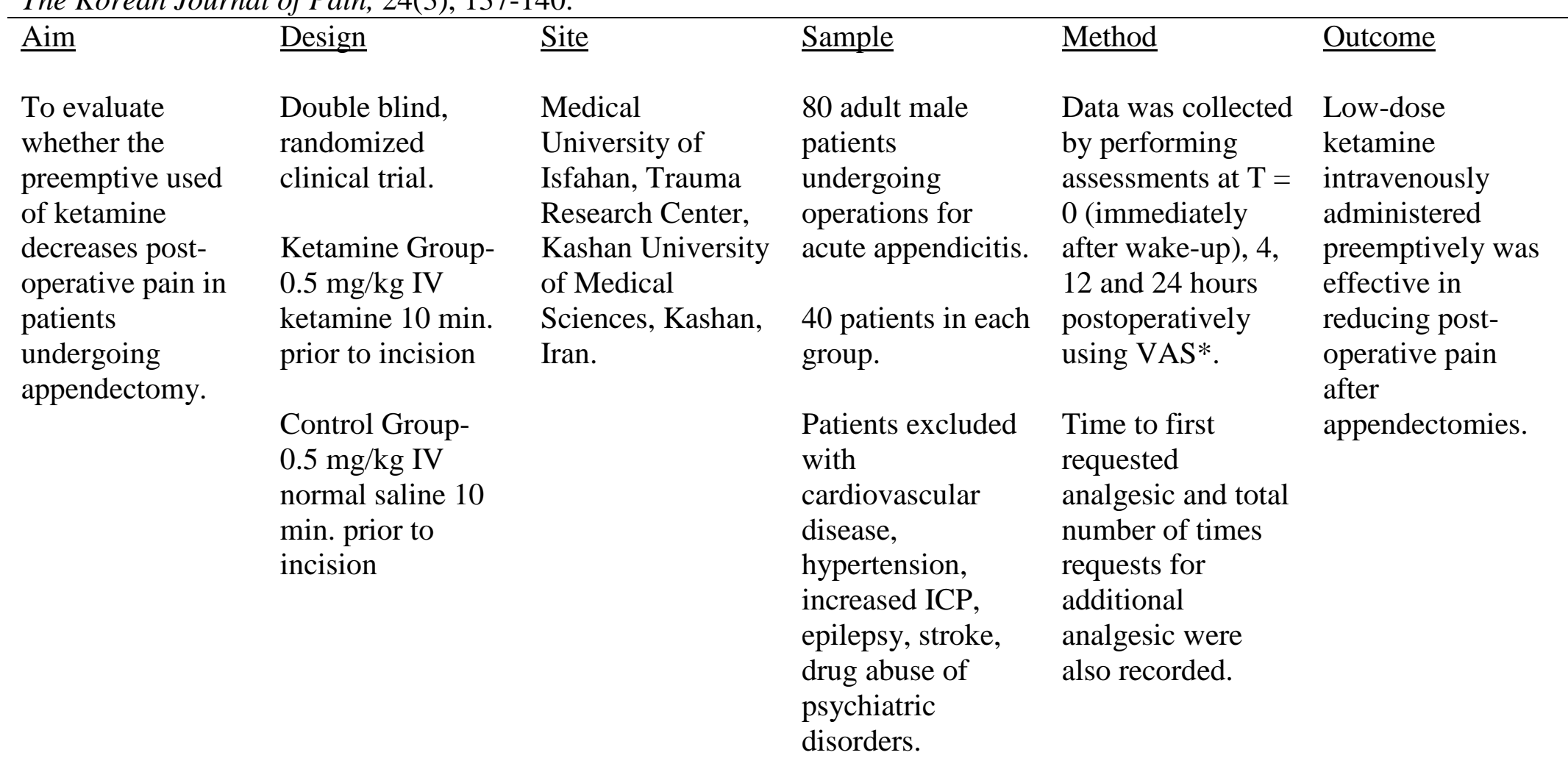

Note. VAS is defined as Visual Analogue Scale. 
Table A.3

\begin{tabular}{|c|c|c|c|c|c|}
\hline$\underline{\text { Aim }}$ & Design & Site & Sample & Method & Procedure \\
\hline $\begin{array}{l}\text { To assess the } \\
\text { effect of } \\
\text { preemptive low- } \\
\text { dose ketamine in } \\
\text { addition to } \\
\text { preemptive } \\
\text { thoracic epidural } \\
\text { analgesia on the } \\
\text { incidence of } \\
\text { chronic post- } \\
\text { thoracotomy pain. }\end{array}$ & $\begin{array}{l}\text { Prospective } \\
\text { randomized, } \\
\text { double-blind } \\
\text { control trial. } \\
\text { Group K- } 0.12 \% \\
\text { levobupivacaine, } 2 \\
\text { mcg/mL fentanyl } \\
\text { and } 0.2 \mathrm{mg} / \mathrm{ml} \\
\text { ketamine for a } \\
\text { total of } 500 \mathrm{~mL} \\
\text { via epidural } \\
\text { infusion } \\
\text { Group KF- } 0.12 \% \\
\text { levobupivacaine, } 2 \\
\text { mcg/ml fentanyl } \\
\text { for a total of } 500 \\
\text { ml via epidural } \\
\text { infusion } \\
\text { Anesthesia and } \\
\text { surgical technique } \\
\text { was the same } \\
\text { between groups. }\end{array}$ & $\begin{array}{l}\text { Seoul National } \\
\text { University } \\
\text { Hospital, Seoul, } \\
\text { South Korea. }\end{array}$ & $\begin{array}{l}133 \text { total patients } \\
\text { were analyzed, } 65 \\
\text { in Group K, } 68 \text { in } \\
\text { Group KF. } \\
\text { Patients with a } \\
\text { history of previous } \\
\text { thoracotomy, } \\
\text { neurological } \\
\text { deficits, localized } \\
\text { systemic } \\
\text { infections or } \\
\text { psychiatric disease } \\
\text { were excluded. }\end{array}$ & $\begin{array}{l}\text { Pain at } \\
\text { thoracotomy scar } \\
\text { site was assessed } \\
\text { at } 2 \text { weeks and } 3 \\
\text { months after } \\
\text { surgery using } \\
\text { VAS*. } \\
\text { Also recorded was } \\
\text { the incidence of } \\
\text { allodynia and } \\
\text { numbness. } \\
\text { Statistical analysis } \\
\text { was performed } \\
\text { using Stata IC } 10 . \\
\text { Fisher's exact test } \\
\text { was also used to } \\
\text { compare the } \\
\text { incidence of } \\
\text { chronic } \\
\text { postthoracotomy } \\
\text { pain. }\end{array}$ & $\begin{array}{l}\text { The addition of } \\
\text { low-dose epidural } \\
\text { ketamine to } \\
\text { preemptive } \\
\text { thoracic epidural } \\
\text { analgesia does not } \\
\text { affect the } \\
\text { incidence of } \\
\text { chronic } \\
\text { postthoracotomy } \\
\text { pain at } 3 \text { months } \\
\text { after thoracotomy. }\end{array}$ \\
\hline
\end{tabular}

Note. VAS is defined as Visual Analogue Scale. 


\section{Table A.4}

Singh, H., Kundra, S., Singh, R., Grewal, A., Kaul, T., \& Sood, D. (2013). Preemptive analgesia with ketamine for a laparoscopic cholecystectomy. Journal of Anesthesiology Clinical Pharmacology, 29 (4), 478-484.

\begin{tabular}{|c|c|c|c|c|c|}
\hline Aim & Design & Site & Sample & Method & Outcome \\
\hline $\begin{array}{l}\text { To evaluate } \\
\text { preemptive } \\
\text { analgesic efficacy } \\
\text { of intravenous } \\
\text { ketamine in } \\
\text { patients } \\
\text { undergoing } \\
\text { laparoscopic } \\
\text { cholecystectomy. }\end{array}$ & 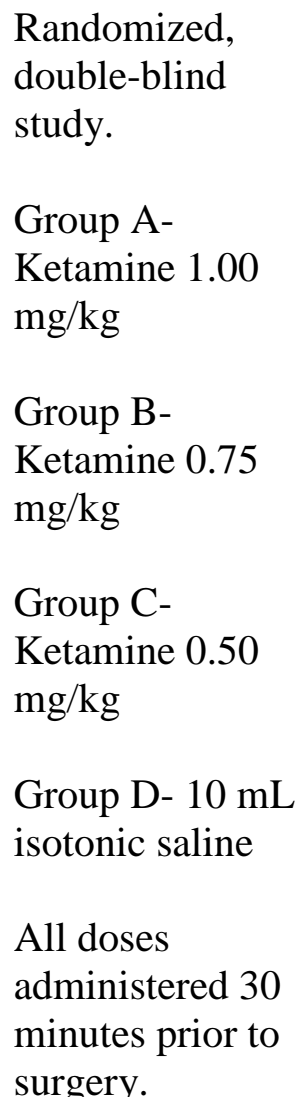 & $\begin{array}{l}\text { Dayanand Medical } \\
\text { Hospital, } \\
\text { Ludhiana, Punjab, } \\
\text { India. }\end{array}$ & $\begin{array}{l}80 \text { patients total, } \\
20 \text { per group. . } \\
\text { All patients } \\
\text { undergoing } \\
\text { laparoscopic } \\
\text { surgery and ASA } \\
\text { I-III. } \\
\text { Patients with a } \\
\text { history of drug } \\
\text { abuse, unable to } \\
\text { comprehend the } \\
\text { VAS scale, } \\
\text { psychiatric } \\
\text { illnesses or } \\
\text { communication } \\
\text { difficulties were } \\
\text { excluded. }\end{array}$ & $\begin{array}{l}\text { Pain assessed at } \\
\text { time intervals } \\
\text { post-op with the } \\
\text { patient at rest, } \\
\text { moving slightly, } \\
\text { and deep breathing } \\
\text { using VAS* } \\
\text { scores. } \\
\text { Time intervals } \\
\text { were every } 30 \\
\text { minutes for } 2 \\
\text { hours, every hour } \\
\text { for } 4 \text { hours, and at } \\
12 \text { hours and } 24 \\
\text { hours. } \\
\text { Requests for } \\
\text { additional } \\
\text { analgesia, adverse } \\
\text { effects, and PONV } \\
\text { were also } \\
\text { recorded. }\end{array}$ & $\begin{array}{l}\text { Low-dose } \\
\text { ketamine } \\
\text { administered } \\
\text { before surgical } \\
\text { incision has } \\
\text { preemptive effect } \\
\text { on postoperative } \\
\text { pain and reduced } \\
\text { analgesic } \\
\text { requirements } \\
\text { during the first } 24 \\
\text { hours after a } \\
\text { laparoscopic } \\
\text { cholecystectomy. }\end{array}$ \\
\hline
\end{tabular}

Note.VAS is defined as Visual Analogue Scale. 
Table A.5

\begin{tabular}{|c|c|c|c|c|c|}
\hline \\
\hline \multicolumn{6}{|c|}{ 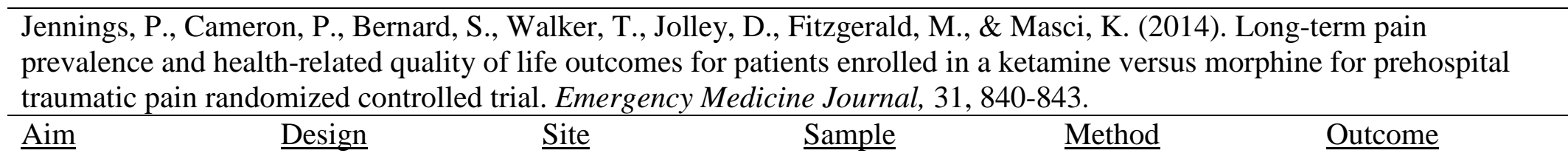 } \\
\hline $\begin{array}{l}\text { Determine the } \\
\text { prevalence of } \\
\text { persistent pain and } \\
\text { whether there } \\
\text { were differences } \\
\text { in patients who } \\
\text { received ketamine } \\
\text { or morphine. }\end{array}$ & $\begin{array}{l}\text { Prehospital, } \\
\text { prospective, } \\
\text { randomized } \\
\text { controlled study, } \\
\text { long-term follow- } \\
\text { up. } \\
\text { Ketamine Group- } \\
20 \text { mg IV bolus } \\
\text { ketamine + } 10 \text { mg } \\
\text { every } 3 \text { minutes } \\
\text { until pain free }\end{array}$ & $\begin{array}{l}\text { Prehospital via } \\
\text { Ambulance } \\
\text { Victoria. Located } \\
\text { in Melbourne, } \\
\text { Australia. }\end{array}$ & $\begin{array}{l}97 \text { total patients } \\
\text { all with isolated } \\
\text { musculoskeletal } \\
\text { trauma and initial } \\
\text { verbal pain score } \\
>5 . \\
70 \text { patients } \\
\text { enrolled in the } \\
\text { ketamine group. }\end{array}$ & $\begin{array}{l}\text { Verbal Numerical } \\
\text { Rating Scales } \\
\text { were compared } \\
\text { using Wilcoxon } \\
\text { rank-sum test. } \\
\text { Component } \\
\text { Summary Scales } \\
\text { were compared } \\
\text { using the two- } \\
\text { sample t-test. }\end{array}$ & $\begin{array}{l}\text { Prevalence of pain } \\
\text { was approximately } \\
\text { the same in both } \\
\text { study groups. }\end{array}$ \\
\hline
\end{tabular}


Table A.6

Khashan, M., Dolkart, O., Amar, E., Chechik, O., Sharfman, Z., Mozes, G., Maman, E., \& Weinbroum, A. (2016). Effect of preemptive intra-articular morphine and ketamine on pain after arthroscopic rotator cuff repair: a prospective, double-blind, randomized controlled study. Arthroscopy and Sports Medicine, 136, 233-239.

\begin{tabular}{|c|c|c|c|c|c|}
\hline$\underline{\text { Aim }}$ & Design & Site & Sample & Method & $\underline{\text { Outcome }}$ \\
\hline $\begin{array}{l}\text { To compared the } \\
\text { postoperative anti- } \\
\text { nociceptive effects } \\
\text { of pre-incisional } \\
\text { intra-articular } \\
\text { ketamine when } \\
\text { combined with } \\
\text { morphine with } \\
\text { two times the dose } \\
\text { of morphine or } \\
\text { saline. }\end{array}$ & $\begin{array}{l}\text { Prospective, } \\
\text { randomized, } \\
\text { double-blind } \\
\text { study. } \\
\text { Patients separated } \\
\text { into } 3 \text { groups, } \\
\text { treated } 20 \text { minutes } \\
\text { prior to incision } \\
\text { with sub-acromial } \\
\text { injections. } \\
\text { M Group- } \\
\text { morphine } 20 \\
\text { mg/ml } \\
\text { KM Group- } \\
\text { ketamine } 50 \text { mg + } \\
\text { morphine } 10 \\
\text { mg/ml } \\
\text { S Group- } 0.9 \% \\
\text { saline } 10 \text { ml }\end{array}$ & $\begin{array}{l}\text { Shoulder unit and } \\
\text { post-operative } \\
\text { care unit, Tel Aviv } \\
\text { Medical Center, } \\
\text { Tel Aviv, Israel. }\end{array}$ & $\begin{array}{l}52 \text { patients } \\
\text { enrolled total, } 17 \\
\text { in M Group, } 19 \text { in } \\
\text { KM group, } 16 \text { in S } \\
\text { group. } \\
\text { All patients } \\
\text { undergoing } \\
\text { arthroscopic } \\
\text { rotator cuff repair } \\
\text { via general } \\
\text { anesthesia. }\end{array}$ & $\begin{array}{l}\text { Patients were } \\
\text { connected to an IV } \\
\text { PCA to deliver } 1.5 \\
\text { mg morphine } \\
\text { boluses. } \\
\text { Pain NRS* and } \\
\text { vitals were } \\
\text { recorded every } 30 \\
\text { min. in PACU, } \\
\text { every } 8 \text { hours on } \\
\text { medical floor. }\end{array}$ & $\begin{array}{l}\text { The use of } \\
\text { morphine alone } \\
\text { provided } \\
\text { consistent } \\
\text { analgesic benefit } \\
\text { when compared to } \\
\text { the control group } \\
\text { and in a greater } \\
\text { benefit than the } \\
\text { morphine and } \\
\text { ketamine group. } \\
\text { Not statistically } \\
\text { significant. }\end{array}$ \\
\hline
\end{tabular}

Note. NRS is defined as Numeric Rating Scale. 
Table A.7

\begin{tabular}{|c|c|c|c|c|c|}
\hline$\underline{\text { Aim }}$ & Design & $\underline{\text { Site }}$ & Sample & Method & $\underline{\text { Outcome }}$ \\
\hline $\begin{array}{l}\text { To determine the } \\
\text { effects of } \\
\text { preemptive } \\
\text { ketamine on } \\
\text { visceral pain in } \\
\text { patients } \\
\text { undergoing } \\
\text { gynecological } \\
\text { laparoscopic } \\
\text { surgery. }\end{array}$ & $\begin{array}{l}\text { Prospective, } \\
\text { randomized, } \\
\text { double-blind } \\
\text { study. } \\
\text { Group 1- IV 0.9\% } \\
\text { saline, pre- } \\
\text { incision } \\
\text { Group 2- } \\
\text { IV 0.9\% saline } \\
\text { pre-incision, } 20 \\
\text { mL Ropivacaine } \\
\text { via local } \\
\text { infiltration at end } \\
\text { of surgery } \\
\text { Group } 3- \\
\text { Ketamine } 0.3 \\
\text { mg/kg pre- } \\
\text { incision, } 20 \text { mL } \\
\text { ropivacaine via } \\
\text { local infiltration at } \\
\text { end of surgery }\end{array}$ & $\begin{array}{l}\text { People's Hospital } \\
\text { of Henan } \\
\text { Province, } \\
\text { Zhengzhou, } \\
\text { China. Peking } \\
\text { University Third } \\
\text { Hospital, Beijing, } \\
\text { China. }\end{array}$ & $\begin{array}{l}88 \text { total patients, } \\
29 \text { in group } 1,29 \\
\text { in group 2, } 30 \text { in } \\
\text { group } 3 . \\
\text { Patients with } \\
\text { preexisting } \\
\text { neurological or } \\
\text { psychiatric } \\
\text { illnesses, patients } \\
\text { with severe organ } \\
\text { disease, patients } \\
\text { with chronic pain } \\
\text { or history of drug } \\
\text { or alcohol abuse } \\
\text { were excluded. }\end{array}$ & $\begin{array}{l}\text { Parietal and } \\
\text { visceral pain } \\
\text { assessed using the } \\
\text { VAS* at 2, 6, 12, } \\
\text { and } 24 \text { hours post- } \\
\text { op. Referred } \\
\text { shoulder pain was } \\
\text { also recorded. } \\
\text { VAS scores above } \\
\text { 4, tramadol was } \\
\text { administered } \\
\text { followed by } \\
\text { intramuscular } \\
\text { injection of } \\
\text { meperidine if no } \\
\text { relief was } \\
\text { achieved. } \\
\text { Data compared } \\
\text { between groups by } \\
\text { analysis of } \\
\text { variance, post-hoc } \\
\text { testing and chi- } \\
\text { square tests. }\end{array}$ & $\begin{array}{l}\text { Preemptive } \\
\text { ketamine was } \\
\text { effective in } \\
\text { controlling post- } \\
\text { operative visceral } \\
\text { pain. }\end{array}$ \\
\hline
\end{tabular}

Note. VAS is defined as Visual Analogue Scale 
Appendix B

Data Collection Tables

\section{Table B.1}

Wilson, J., Nimmo, A., Fleetwood-Walker, S., \& Colvin, L. (2008). A randomized double blind trial of the effect of the preemptive epidural ketamine on persistent pain after lower limb amputation. Pain, 135, 108-118.

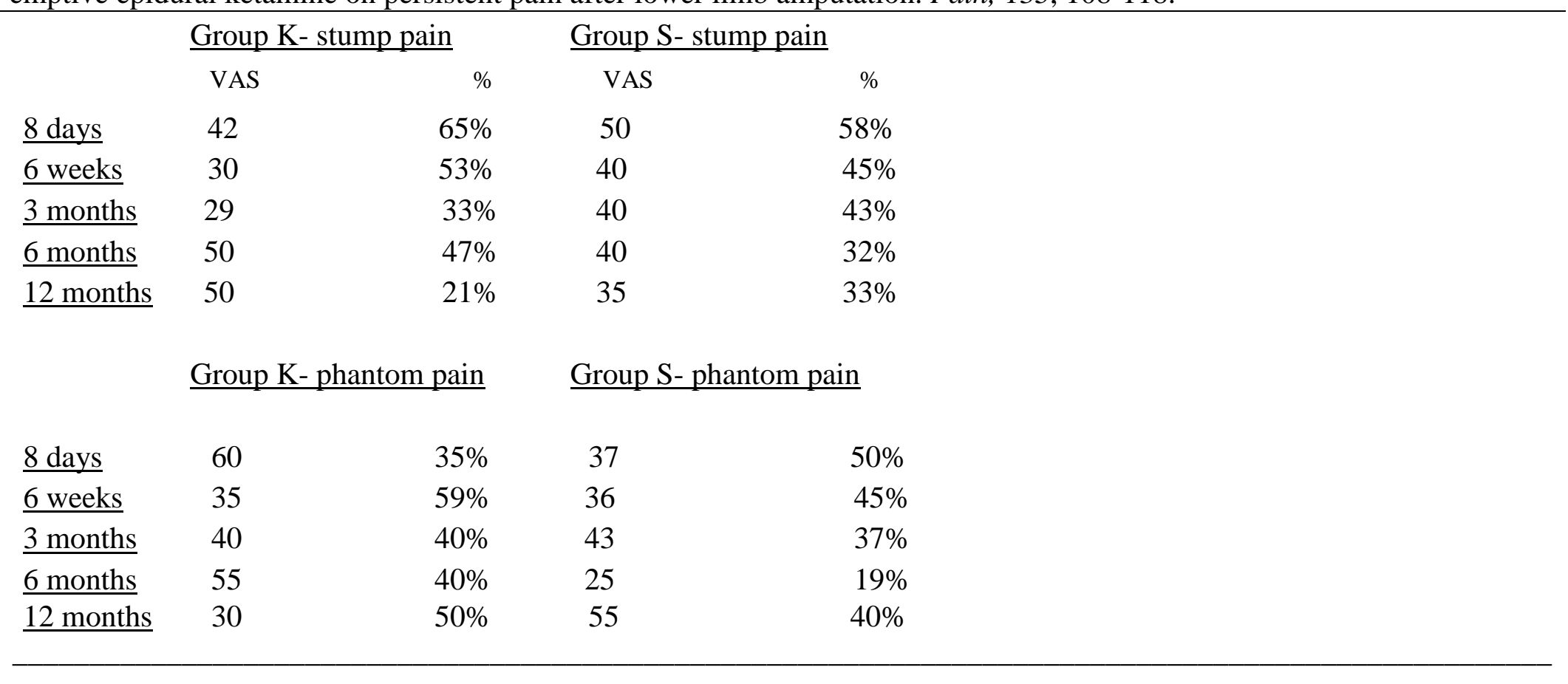

Note. Data shown are VAS (visual analogue scale) scores followed by percentages of those experiencing pain over total number in the group at each time point for both groups for up to 12 months following surgery. 
Table B.2

Behdad, A., Hosseinpour, M., Khorasani, P. (2011). Preemptive use of ketamine on post-operative pain of appendectomy.

The Korean Journal of Pain, 24(3), 137-140.

\begin{tabular}{rrrr}
\hline \multicolumn{2}{r}{ Ketamine Group } & \multicolumn{1}{c}{ Control Group } & \multicolumn{1}{c}{ P-value } \\
\cline { 3 - 3 } Time (hrs) & $4.5 \pm 1.0$ & $6.6 \pm 1.1$ & 0.017 \\
$\underline{4}$ & $4.7 \pm 0.1$ & $4.7 \pm 1.0$ & 0.045 \\
$\underline{12}$ & $2.2 \pm 1.1$ & $3.5 \pm 0.9$ & 0.039 \\
$\underline{24}$ & $1.3 \pm 0.5$ & $1.8 \pm 0.6$ & 0.044 \\
\hline
\end{tabular}

Note. Scores indicate Visual Analogue Score (VAS) in each group at the given time interval with reported standard deviations. 


\section{Table B.3}

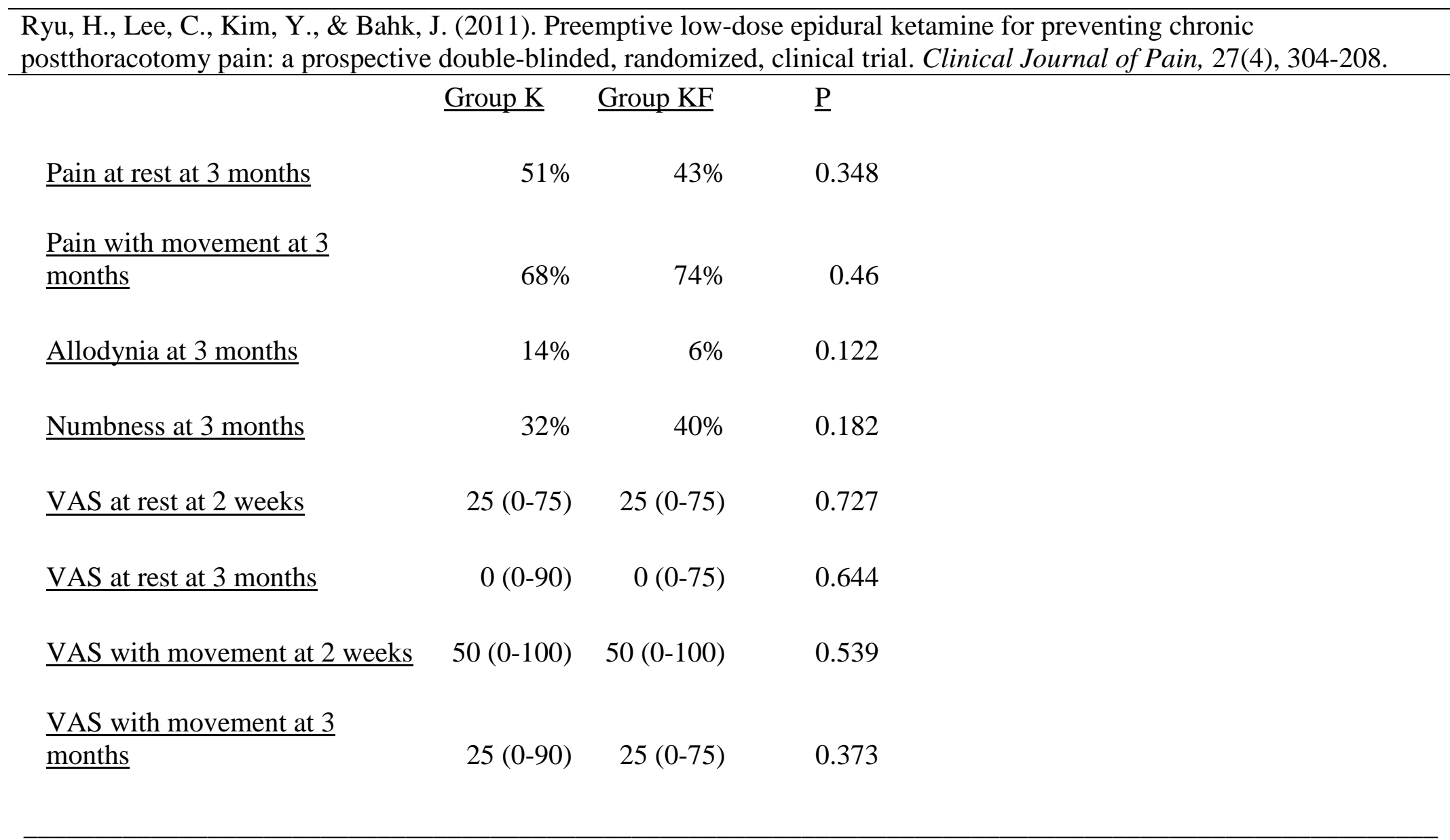

Note. Data are proportions or median (range). 
Table B.4

\begin{tabular}{|c|c|c|}
\hline \multicolumn{3}{|c|}{$\begin{array}{l}\text { Singh, H., Kundra, S., Singh, R., Grewal, A., Kaul, T., \& Sood, D. (2013). Preemptive analgesia with ketamine for a } \\
\text { laparoscopic cholecystectomy. Journal of Anesthesiology Clinical Pharmacology, } 29 \text { (4), 478-484. }\end{array}$} \\
\hline & \# of doses of rescue analgesic & Mean time to the requirement of rescue analgesic \\
\hline Group A & 4.55 & 2.1 \\
\hline Group B & 4.45 & 1.85 \\
\hline Group C & 4.25 & 1.98 \\
\hline Group D & 7.35 & 0.375 \\
\hline
\end{tabular}

Note. Mean time to the requirement of rescue analgesic measured in hours. Group A received $1.0 \mathrm{mg} / \mathrm{kg}$ ketamine IV. Group B received $0.75 \mathrm{mg} / \mathrm{kg}$ ketamine IV. Group C received $0.50 \mathrm{mg} / \mathrm{kg}$ ketamine IV. Group D received isotonic saline. 
Table B.5

Jennings, P., Cameron, P., Bernard, S., Walker, T., Jolley, D., Fitzgerald, M., \& Masci, K. (2014). Long-term pain prevalence and health-related quality of life outcomes for patients enrolled in a ketamine versus morphine for prehospital traumatic pain randomized controlled trial. Emergency Medicine Journal, 31, 840-843

\begin{tabular}{|c|c|c|c|c|c|c|c|}
\hline & \multirow[b]{2}{*}{ \# } & \multicolumn{3}{|c|}{ Physical Component Summary Score } & \multicolumn{3}{|c|}{ Mental Component Summary Score } \\
\hline & & $\underline{\mathrm{K}+\mathrm{M} \text { Group }}$ & $\underline{\text { M Group }}$ & p Value & $\underline{\mathrm{K}+\mathrm{M} \text { Group }}$ & M Group & p Value \\
\hline \multicolumn{8}{|c|}{ Injury Severity Score } \\
\hline$\underline{0-4}$ & 77 & 49.1 & 47.8 & 0.61 & 49.2 & 49.4 & 0.94 \\
\hline 14-May & 14 & 51.3 & 50.9 & 0.93 & 55.2 & 56.4 & 0.76 \\
\hline$\underline{15+}$ & 6 & 37.8 & 44.9 & 0.62 & 46.4 & 45.5 & 0.94 \\
\hline \multicolumn{8}{|l|}{ Initial Pain Score } \\
\hline 7-May & 51 & 51.4 & 48.8 & 0.28 & 52 & 51.3 & 0.82 \\
\hline 10-Aug & 46 & 46.1 & 47 & 0.82 & 47.7 & 48.6 & 0.84 \\
\hline \multicolumn{8}{|l|}{ Final Pain Score } \\
\hline$\underline{0-4}$ & 68 & 49.1 & 49.2 & 0.98 & 50 & 49.6 & 0.92 \\
\hline 7-May & 22 & 56.2 & 44.7 & 0.08 & 53.3 & 48.3 & 0.54 \\
\hline 10-Aug & 7 & 30.9 & 53.4 & 0.03 & 45.3 & 57.7 & 0.12 \\
\hline \multicolumn{8}{|l|}{ Prehospital Time } \\
\hline$<60$ min. & 68 & 48.4 & 48.6 & 0.94 & 50.5 & 48.6 & 0.57 \\
\hline$>60$ min. & 29 & 50.1 & 45.9 & 0.25 & 49.2 & 53.9 & 0.24 \\
\hline \multicolumn{8}{|l|}{ Case Nature } \\
\hline Extremity Fracture & 33 & 47.1 & 48.7 & 0.61 & 47.2 & 52.3 & 0.28 \\
\hline Soft Tissue Injury & 26 & 52.5 & 48.2 & 0.41 & 52 & 48.9 & 0.56 \\
\hline Fracture, other & 21 & 47.8 & 45.6 & 0.64 & 49.5 & 47.2 & 0.73 \\
\hline Dislocation & 15 & 45.7 & 47 & 0.86 & 51 & 48.7 & 0.63 \\
\hline Burn & 2 & 58.4 & 59.6 & NA & 57.4 & 52.6 & NA \\
\hline
\end{tabular}




\section{Table B.6}

Khashan, M., Dolkart, O., Amar, E., Chechik, O., Sharfman, Z., Mozes, G., Maman, E., \& Weinbroum, A. (2016). Effect of preemptive intra-articular morphine and ketamine on pain after arthroscopic rotator cuff repair: a prospective, double-blind, randomized controlled study. Arthroscopy and Sports Medicine, 136, 233-239.

\begin{tabular}{|c|c|c|c|c|}
\hline & $\underline{\text { M Group }(n=17)}$ & $\underline{\text { KM Group }(n=19)}$ & $\underline{\text { S Group }(n=17)}$ & $\underline{\text { P-value }}$ \\
\hline$\underline{\text { PACU }}$ & $4.15 \pm 0.51$ & $5.29 \pm 0.57$ & $4.32 \pm 0.43$ & 0.25 \\
\hline On Ward & $3.37 \pm 0.31$ & $4.75 \pm 0.43$ & $4.71 \pm 0.50$ & $0.041^{*}$ \\
\hline$\underline{1 \text { st post-op week }}$ & $4.93 \pm 0.36$ & $5.98 \pm 0.61$ & $6.83 \pm 0.90$ & $0.035 *$ \\
\hline 2nd post-op week & $3.79 \pm 0.45$ & $5.44 \pm 0.72$ & $6.41 \pm 0.57$ & $0.013^{*}$ \\
\hline 3 months post-op & $3.0 \pm 0.56$ & $4.0 \pm 0.62$ & $2.80 \pm 0.40$ & 0.25 \\
\hline$\underline{\text { PCA morphine }}$ & $21.6 \pm 3.1$ & $18.2 \pm 2.9$ & $17.3 \pm 3.4$ & 0.6 \\
\hline Wk 1 - Paracetamol & $0.76 \pm 0.18$ & $0.95 \pm 0.17$ & $1.0 \pm 0.22$ & 0.64 \\
\hline Wk 1- Oxycodone & $1.15 \pm 0.25$ & $1.7 \pm 0.24$ & $1.3 \pm 0.29$ & 0.26 \\
\hline Wk 2- Paracetamol & $0.52 \pm 0.18$ & $0.91 \pm 0.2$ & $0.94 \pm 0.25$ & 0.32 \\
\hline Wk 2- Oxycodone & $0.79 \pm 0.21$ & $1.4 \pm 0.56$ & $1.15 \pm 0.25$ & 0.53 \\
\hline
\end{tabular}




\section{Table B.7}

Lin, H., \& Jia, D. (2016). Effect of preemptive ketamine administration on postoperative visceral pain after gynecological laparoscopic surgery. Journal of Huazhong University of Science and Technology, 36(4), 584-587.

Group $1 \quad$ Group $2 \quad$ Group 3

Visceral Pain

$\begin{aligned} \underline{2 \text { hours }} & 6.2 \pm 1.2 \\ \underline{6 \text { hours }} & 5.1 \pm 1.1 \\ \underline{12 \text { hours }} & 3.1 \pm 0.8 \\ \underline{24 \text { hours }} & 2.6 \pm 1.0\end{aligned}$

$$
\begin{aligned}
& 5.8 \pm 1.8 \\
& 5.2 \pm 1.2 \\
& 2.6 \pm 0.6 \\
& 2.5 \pm 0.8
\end{aligned}
$$$$
3.1 \pm 1.3
$$$$
2.9 \pm 1.2
$$$$
2.5 \pm 0.5
$$$$
2.4 \pm 0.8
$$

Incisional Pain

$\begin{array}{rrrr}\underline{2 \text { hours }} & 6.6 \pm 2.0 & 3.3 \pm 1.7 & 3.1 \pm 1.6 \\ \underline{\underline{6 \text { hours }}} & 5.1 \pm 1.6 & 3.1 \pm 1.5 & 2.8 \pm 1.2 \\ \underline{\underline{12 \text { hours }}} & 2.8 \pm 1.5 & 2.7 \pm 1.4 & 2.6 \pm 1.1 \\ \underline{24 \text { hours }} & 2.6 \pm 1.5 & 2.7 \pm 1.6 & 2.4 \pm 1.6 \\ \underline{\text { Meperidine }} & 23^{*} & 18^{*} & 18^{*} \\ \underline{\text { Dose per pt (mg) }} & 98 \pm 17.5 & 52.5 \pm 14.5 & 54.2 \pm 16.4 \\ \frac{\text { No analgesics }}{\text { required }} & 6 & 11 & 12\end{array}$

Note. * indicates number of people in the specified group that requested additional analgesic. All numbers are pain scores reported via Visual Analogue Scale and standard deviations. 


\section{Appendix C}

\section{Critical Appraisal Skills Programme (CASP)}

\section{Table C.1}

Wilson, J., Nimmo, A., Fleetwood-Walker, S., \& Colvin, L. (2008). A randomized double blind trial of the effect of the pre-emptive epidural ketamine on persistent pain after lower limb amputation. Pain, 135, 108-118.
A) Are the results of the trial valid?

1. Did the trial address a clearly focused issue?

2. Was the assignment of patients to treatments randomized?

3. Were all the patients who entered the trial properly accounted for at its conclusion?

4. Were patients, health workers and study personnel "blind" to treatment?

5 . Were the groups similar at the start of the trial?

6. Aside from the experimental intervention, were the groups treated equally?

\section{B) What are the results?}

7. How large was the treatment effect?

8. How precise was the estimate of the treatment effect?

\section{C) Will the results help locally?}

9. Can the results be applied in your context?

10. Were all clinically important outcomes considered?

11. Are the benefits worth the harms and costs?

$\begin{array}{ccc}\text { Yes } & \text { Can’t Tell } & \text { No } \\ \checkmark & & \\ \checkmark & \end{array}$

No

47 total patients assigned to treatment groups

Box and whisker plots graphed VAS scores for stump and phantom pain at different time intervals. The incidence and frequency of pain was also recorded for each group.
Yes
Can't Tell
No

Note. VAS indicates Visual Analogue Scale. 


\section{Table C.2}

Behdad, A., Hosseinpour, M., Khorasani, P. (2011). Preemptive use of ketamine on post-operative pain of appendectomy. The Korean Journal of Pain, 24(3), 137-140.
A) Are the results of the trial valid?
1. Did the trial address a clearly focused issue?
2. Was the assignment of patients to treatments randomized?
3. Were all the patients who entered the trial properly accounted for at its conclusion?
4. Were patients, health workers and study personnel "blind" to treatment?
5 . Were the groups similar at the start of the trial?
6. Aside from the experimental intervention, were the groups treated equally?

Yes

Can't Tell

No

\section{B) What are the results?}

7. How large was the treatment effect?

8. How precise was the estimate of the treatment effect?

\section{C) Will the results help locally?}

9. Can the results be applied in your context?

10. Were all clinically important outcomes considered?

11. Are the benefits worth the harms and costs?
80 adult male patients assigned to treatment/control groups

Using the VAS scale, pain scores collected at time $0,4,12$, and 24 hours post-operatively. The time interval for first requested analgesia was also recorded.
Yes
Can't Tell
No 


\section{Table C.3}

Ryu, H., Lee, C., Kim, Y., \& Bahk, J. (2011). Preemptive low-dose epidural ketamine for preventing chronic postthoracotomy pain: a prospective double-blinded, randomized, clinical trial. Clinical Journal of Pain, 27(4), 304-208.
A) Are the results of the trial valid?
1. Did the trial address a clearly focused issue?
2. Was the assignment of patients to treatments randomized?
3. Were all the patients who entered the trial properly accounted for at its conclusion?
4. Were patients, health workers and study personnel "blind" to treatment?
5. Were the groups similar at the start of the trial?
6. Aside from the experimental intervention, were the groups treated equally?

Yes

Can't Tell

No

\section{B) What are the results?}

7. How large was the treatment effect?

8. How precise was the estimate of the treatment effect?

\section{C) Will the results help locally?}

9. Can the results be applied in your context?
133 patients’ data were analyzed

VAS scores were assessed during rest and movement at 2 weeks and 3 months after surgery. Allodynia and numbness at the scar site was also documented.

Yes Can't Tell No

10. Were all clinically important outcomes considered?

11. Are the benefits worth the harms and costs?

Note. VAS indicates Visual Analogue Scale. 


\section{Table C.4}

Singh, H., Kundra, S., Singh, R., Grewal, A., Kaul, T., \& Sood, D. (2013). Preemptive analgesia with ketamine for a laparoscopic cholecystectomy. Journal of Anesthesiology Clinical Pharmacology, 29 (4), 478-484.
A) Are the results of the trial valid?
1. Did the trial address a clearly focused issue?
2. Was the assignment of patients to treatments randomized?
3. Were all the patients who entered the trial properly accounted for at its conclusion?
4. Were patients, health workers and study personnel "blind" to treatment?
5. Were the groups similar at the start of the trial?
6. Aside from the experimental intervention, were the groups treated equally?

\section{B) What are the results?}

7. How large was the treatment effect?

8. How precise was the estimate of the treatment effect?

\section{C) Will the results help locally?}

9. Can the results be applied in your context?

10. Were all clinically important outcomes considered?

11. Are the benefits worth the harms and costs?
80 patients assigned to treatment/control groups

Mean VAS and VRS scores were graphed for trend analysis. Total opioid consumption and time to rescue analgesia were recorded and compared.

\section{Yes Can't Tell No}

Note. VAS indicates Visual Analogue Scale. VRS indicates Verbal Rating Scale. 


\section{Table C.5}

Jennings, P., Cameron, P., Bernard, S., Walker, T., Jolley, D., Fitzgerald, M., \& Masci, K. (2014). Long-term pain prevalence and health-related quality of life outcomes for patients enrolled in a ketamine versus morphine for prehospital traumatic pain randomized controlled trial. Emergency Medicine Journal, 31, 840-843.
A) Are the results of the trial valid?
1. Did the trial address a clearly focused issue?
2. Was the assignment of patients to treatments randomized?
3. Were all the patients who entered the trial properly accounted for at its conclusion?
4. Were patients, health workers and study personnel "blind" to treatment?
5. Were the groups similar at the start of the trial?
6. Aside from the experimental intervention, were the groups treated equally?

\section{B) What are the results?}

7. How large was the treatment effect?

8. How precise was the estimate of the treatment effect?

\section{C) Will the results help locally?}

9. Can the results be applied in your context?

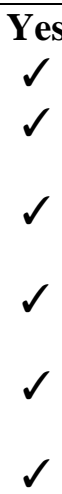

$\checkmark$

Can't Tell

No
97 patients total, no difference in pain prevalence telephone interviews performed to obtain PCS and MCS scores

10. Were all clinically important outcomes considered?

11. Are the benefits worth the harms and costs?

Note. Follow up was possible in $72 \%$ of patients. Authors did not have access to "time to treatment” information and felt that this was an important covariate that should have been collected. 


\section{Table C.6}

Khashan, M., Dolkart, O., Amar, E., Chechik, O., Sharfman, Z., Mozes, G., Maman, E., \& Weinbroum, A. (2016). Effect of preemptive intra-articular morphine and ketamine on pain after arthroscopic rotator cuff repair: a prospective, double-blind, randomized controlled study. Arthroscopy and Sports Medicine, 136, 233-239.
A) Are the results of the trial valid?
1. Did the trial address a clearly focused issue?
2. Was the assignment of patients to treatments randomized?
3. Were all the patients who entered the trial properly accounted for at its conclusion?
4. Were patients, health workers and study personnel "blind" to treatment?
5. Were the groups similar at the start of the trial?
6. Aside from the experimental intervention, were the groups treated equally?

Yes

$\checkmark$

\section{B) What are the results?}

7. How large was the treatment effect?

8. How precise was the estimate of the treatment effect?

\section{C) Will the results help locally?}

9. Can the results be applied in your context?

10. Were all clinically important outcomes considered?

11. Are the benefits worth the harms and costs?
Can't Tell

No
30 patients assigned to treatment groups

Pain scores were recorded at several time intervals following surgery and up to 3 months post-operatively using NRS. Pain medicine consumption was also recorded.

Yes

Can't Tell

Note. NRS indicates Numeric Rating Scale. 


\section{Table C.7}

Lin, H., \& Jia, D. (2016). Effect of preemptive ketamine administration on postoperative visceral pain after gynecological laparoscopic surgery. Journal of Huazhong University of Science and Technology, 36(4), 584-587.
A) Are the results of the trial valid?
1. Did the trial address a clearly focused issue?
2. Was the assignment of patients to treatments randomized?
3. Were all the patients who entered the trial properly accounted for at its conclusion?
4. Were patients, health workers and study personnel "blind" to treatment?
5 . Were the groups similar at the start of the trial?
6. Aside from the experimental intervention, were the groups treated equally?

Yes

Can't Tell

No

\section{B) What are the results?}

7. How large was the treatment effect?

8. How precise was the estimate of the treatment effect?

\section{C) Will the results help locally?}

9. Can the results be applied in your context?

10. Were all clinically important outcomes considered?

11. Are the benefits worth the harms and costs?
88 patients assigned to treatment groups

Assessment of post-operative pain and visceral pain using VAS scores. Total consumption of analgesics and side effects were also recorded.

Yes Can't Tell No
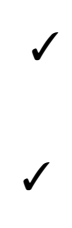
Appendix D

Cross Study Analysis Table

\begin{tabular}{|c|c|c|c|}
\hline Authors & Route & Dosing & Results \\
\hline $\begin{array}{l}\text { Wilson, } \\
\text { Nimmo, } \\
\text { Fleetwood- } \\
\text { Walker \& } \\
\text { Colvin } \\
(2008)\end{array}$ & $\begin{array}{l}\text { Epidurally } \\
\text { administered } \\
\text { ketamine for } \\
\text { lower limb } \\
\text { amputations. }\end{array}$ & $\begin{array}{l}\text { Group K - } 0.125 \% \\
\text { bupivacaine infusion with } \\
3.3 \mathrm{mg} / \mathrm{kg} / \mathrm{l} \text { ketamine. } \\
\text { Group S - } 0.125 \% \\
\text { bupivacaine with } \\
\text { equivalent volume } \mathrm{NaCl} \\
0.9 \% \text {. }\end{array}$ & $\begin{array}{l}\text { Rates of phantom and } \\
\text { stump pain did not differ } \\
\text { between groups at any of } \\
\text { assessments up to one year } \\
\text { post-op. Number of } \\
\text { analgesic drugs prescribed } \\
\text { did not vary between } \\
\text { groups }\end{array}$ \\
\hline $\begin{array}{l}\text { Behdad, } \\
\text { Hosseinpour } \\
\text { \& } \\
\text { Khorasani } \\
\text { (2011). }\end{array}$ & $\begin{array}{l}\text { Intravenously } \\
\text { administered } \\
\text { ketamine for } \\
\text { acute } \\
\text { appendicitis. }\end{array}$ & $\begin{array}{l}\text { Ketamine Group - } 0.5 \\
\mathrm{mg} / \mathrm{kg} \text { IV ketamine } 10 \\
\text { min. prior to incision. } \\
\text { Control Group - } 0.5 \mathrm{mg} / \mathrm{kg} \\
\text { IV normal saline } 10 \mathrm{~min} \text {. } \\
\text { prior to incision }\end{array}$ & $\begin{array}{l}\text { Pain scores were } \\
\text { significantly lower in } \\
\text { Ketamine group. The } \\
\text { control group asked for } \\
\text { additional analgesic faster } \\
\text { than the ketamine group } \\
\text { and more often. }\end{array}$ \\
\hline $\begin{array}{l}\text { Ryu, Lee, } \\
\text { Kim \& } \\
\text { Bahk } \\
\text { (2011). }\end{array}$ & $\begin{array}{l}\text { Epidurally } \\
\text { administered } \\
\text { ketamine for } \\
\text { postthoracotomy } \\
\text { pain. }\end{array}$ & $\begin{array}{l}\text { Group K - } 0.12 \% \\
\text { levobupivacaine, } 2 \\
\text { mcg/mL fentanyl and } 0.2 \\
\mathrm{mg} / \mathrm{ml} \text { ketamine for a total } \\
\text { of } 500 \mathrm{~mL} \text { via epidural } \\
\text { infusion. Group KF - } \\
0.12 \% \text { levobupivacaine, } 2 \\
\text { mcg/ml fentanyl for a total } \\
\text { of } 500 \mathrm{ml} \text { via epidural } \\
\text { infusion. }\end{array}$ & $\begin{array}{l}\text { No difference in } \\
\text { postthoracotomy pain at } 3 \\
\text { months between groups. } \\
\text { No difference of allodynia } \\
\text { or numbness incidence } \\
\text { between groups. }\end{array}$ \\
\hline
\end{tabular}




\begin{tabular}{|c|c|c|c|}
\hline Authors & Context & Participants/Groups & Results \\
\hline $\begin{array}{l}\text { Singh, } \\
\text { Kundra, } \\
\text { Singh, } \\
\text { Grewal, } \\
\text { Kaul \& } \\
\text { Sood } \\
\text { (2017). }\end{array}$ & $\begin{array}{l}\text { Intravenously } \\
\text { administered } \\
\text { ketamine for } \\
\text { patients } \\
\text { undergoing } \\
\text { laparoscopic } \\
\text { cholecystectomy. }\end{array}$ & $\begin{array}{l}\text { Group A- Ketamine } 1.00 \\
\text { mg/kg. Group B- } \\
\text { Ketamine } 0.75 \mathrm{mg} / \mathrm{kg} \text {. } \\
\text { Group C- Ketamine } 0.50 \\
\text { mg/kg. Group D- } 10 \mathrm{~mL} \\
\text { isotonic saline. All doses } \\
\text { administered } 30 \text { minutes } \\
\text { prior to surgery. }\end{array}$ & $\begin{array}{l}\text { Pain scores were } \\
\text { highest in Group D at } \\
0 \text { h post-op. Groups } \\
\text { A, B, \& C had } \\
\text { decreased post-op } \\
\text { pain scores at } 0,0.5 \text {, } \\
3,4,5,6, \& 12 \text { h. } \\
\text { Post-op analgesic } \\
\text { consumption was less } \\
\text { in groups A, B, \& C. } \\
\text { No significant } \\
\text { difference in pain } \\
\text { between groups A, B, } \\
\text { \& C. }\end{array}$ \\
\hline $\begin{array}{l}\text { Jennings, } \\
\text { Cameron, } \\
\text { Bernard, } \\
\text { Walker, } \\
\text { Jolley, } \\
\text { Fitzgerald } \\
\text { \& Masci } \\
\text { (2014). }\end{array}$ & $\begin{array}{l}\text { Intravenously } \\
\text { administered } \\
\text { ketamine on } \\
\text { hospital arrival } \\
\text { for patients with } \\
\text { musculoskeletal } \\
\text { trauma. }\end{array}$ & $\begin{array}{l}\text { Ketamine Group- } 20 \text { mg } \\
\text { IV bolus ketamine }+10 \\
\text { mg every } 3 \text { minutes until } \\
\text { pain free. Morphine } \\
\text { Group- } 5 \text { mg IV bolus } \\
\text { morphine }+5 \text { mg every } \\
5 \text { minutes until pain free. }\end{array}$ & $\begin{array}{l}\text { The prevalence of } \\
\text { persistent pain was } \\
\text { the same between } \\
\text { groups. }\end{array}$ \\
\hline $\begin{array}{l}\text { Khashan, } \\
\text { Dolkart, } \\
\text { Amar, } \\
\text { Chechik, } \\
\text { Sharfman, } \\
\text { Mozes, } \\
\text { Maman \& } \\
\text { Weinbroum } \\
\text { (2016). }\end{array}$ & $\begin{array}{l}\text { Intra-articular } \\
\text { ketamine for } \\
\text { patients } \\
\text { undergoing } \\
\text { arthroscopic } \\
\text { rotator cuff } \\
\text { repair. }\end{array}$ & $\begin{array}{l}\text { M Group- morphine } 20 \\
\text { mg/ml. KM Group- } \\
\text { ketamine } 50 \mathrm{mg}+ \\
\text { morphine } 10 \mathrm{mg} / \mathrm{ml} . \mathrm{S} \\
\text { Group- } 0.9 \% \text { saline } 10 \\
\text { ml }\end{array}$ & $\begin{array}{l}24 \text { h and } 2 \text { week pain } \\
\text { scores were } \\
\text { significantly lower in } \\
\text { treatment groups } \\
\text { compared to placebo, } \\
\text { but did not } \\
\text { significantly differ } \\
\text { between the two. } \\
\text { PCA-morphine and } \\
\text { oral analgesics were } \\
\text { consumed at similar } \\
\text { rates among all } \\
\text { groups. }\end{array}$ \\
\hline
\end{tabular}




\begin{tabular}{|c|c|c|c|}
\hline Authors & Context & Participants/Groups & Results \\
\hline $\begin{array}{l}\text { Lin \& Jia } \\
(2016) .\end{array}$ & $\begin{array}{l}\text { Intravenously } \\
\text { administered } \\
\text { ketamine on } \\
\text { visceral pain for } \\
\text { patients } \\
\text { undergoing } \\
\text { gynecological } \\
\text { laparoscopic } \\
\text { surgery. }\end{array}$ & $\begin{array}{l}\text { Group 1- IV 0.9\% } \\
\text { saline, pre-incision. } \\
\text { Group 2- IV } 0.9 \% \text { saline } \\
\text { preincision, } 20 \mathrm{~mL} \\
\text { Ropivacaine via local } \\
\text { infiltration at end of } \\
\text { surgery. Group 3- } \\
\text { Ketamine } 0.3 \mathrm{mg} / \mathrm{kg} \\
\text { preincision, } 20 \mathrm{~mL} \\
\text { ropivacaine via local } \\
\text { infiltration at end of } \\
\text { surgery. }\end{array}$ & $\begin{array}{l}\text { Pain scores for group } \\
3 \text { were significantly } \\
\text { lower than groups } 1 \text { \& } \\
2 \text { at } 2 \text { h and } 6 \text { h post- } \\
\text { op. Groups } 1 \text { \& } 2 \text { did } \\
\text { not differ at } 2 \text { h and } 6 \\
\text { h post-op. All groups } \\
\text { were not statistically } \\
\text { different at } 12 \text { h and } \\
24 \text { h post-op. } \\
\text { Consumption of } \\
\text { analgesics was } \\
\text { significantly greater in } \\
\text { group } 1 \text { than the other } \\
\text { groups. The time for } \\
\text { first analgesia request } \\
\text { was significantly } \\
\text { longer in groups } 2 \text { \& } \\
3 .\end{array}$ \\
\hline
\end{tabular}

